\title{
38. EVOLUTION OF PALEOENVIRONMENTS OF ERATOSTHENES SEAMOUNT BASED ON DOWNHOLE LOGGING INTEGRATED WITH CARBONATE PETROLOGY AND REFLECTION PROFILES
}

\author{
Candace O. Major, ${ }^{2}$ William B.F. Ryan, ${ }^{2}$ and Maria José Jurado-Rodríguez ${ }^{3}$
}

\begin{abstract}
The sedimentary successions cored and logged at three sites on Eratosthenes Seamount in the Eastern Mediterranean Sea indicate a progression of environments from shallow carbonate platform in the early Cretaceous, to bathyal pelagic during the late Cretaceous and Paleogene, and back to a shallow neritic reef setting in the late Miocene. Deep-water conditions return in the early Pliocene. The majority of the submergence of the summit of the Eratosthenes edifice from the photic zone in the late Miocene to the 700 to $950 \mathrm{~m}$ bathyal zone in the early Pliocene can be explained by the broad isostatic loading of a thick layer of Messinian evaporites and clastics that surrounds this bathymetric high and accumulated in a very brief span of time between 5.8 and 5.32 m.y. ago. Some northward tilting and faulting of the northern margin of the seamount in the past few million years, related to relatively recent interaction with the Cyprus margin, may explain the presence of shallow-water fauna midway down the northern flank.

The Miocene to Holocene sedimentary units recovered during Leg 160 are correlated with sedimentary sections described from the Levant and Egyptian margins. This indicates a predominant sedimentary and isostatic loading control on the evolution of the Eratosthenes Seamount before its relatively recent entry into the Cyprus subduction zone.
\end{abstract}

\section{INTRODUCTION}

Eratosthenes Seamount (Fig. 1) is a broad, oval-shaped edifice located in the Levantine Basin south of the island of Cyprus in the Eastern Mediterranean. This so-called seamount is characterized by a relatively wide summit plateau (Fig. 2) whose long axis approaches 45 $\mathrm{km}$. The seamount displays a substantial magnetic anomaly with a magnitude of 400 nannoteslas (nT) in the otherwise magnetically subdued setting of the submerged African Plate (Makris et al., 1994). Seismic reflection profiling suggests that the sediment cover on the seamount is $\sim 5 \mathrm{~km}$ (Makris et al., 1994). Analysis of the regional gravity field further suggests that the seamount is a continental fragment with a crustal thickness of $\sim 25 \mathrm{~km}$, draped predominantly by Mesozoic sediments (Makris and Wang, 1994).

The present summit of the seamount protrudes through the thick sedimentary succession of Neogene and Paleogene strata of the continental slopes and rises of the Levant and African margins (Fig. 3), including a thick layer of evaporite deposits and intercalated clastics belonging to the Messinian Stage of the late Miocene (Ryan, 1978). These evaporites were deposited during a brief interval 5.8 to 5.32 Ma (Hodell et al., 1994), when the Mediterranean was isolated from the world ocean and Mediterranean sea level was drawn down by excessive evaporation, leaving the basin strongly desiccated (Hsü et al., 1973a; Hsü et al., 1977; Hsü et al., 1973b) and exposing the shallow marginal areas and bathymetric highs. Consequently the evaporites are not expressed as a bed of any substantial thickness on the edifice itself, but instead pinch out against the seamount flanks at a depth between 2 and $3 \mathrm{~km}$. In their place on the seamount summit and flank one observes a highly reverberant erosion surface (Fig. 4) (the so-

${ }^{1}$ Robertson, A.H.F., Emeis, K.-C., Richter, C., and Camerlenghi, A. (Eds.), 1998. Proc. ODP, Sci. Results, 160: College Station, TX (Ocean Drilling Program).

${ }^{2}$ Borehole Research Group, Lamont-Doherty Earth OBservatory, Columbia University, Palisades, NY 10964, U.S.A. Major@lamont.ldeo.columbia.edu

${ }^{3}$ Geophysikalisches Institut, University of Karlsruhe, Herzstrasse 16, D-76187 Karlsruhe, Federal Republic of Germany. called M reflector) similar to that found on other Mediterranean continental margins (Ryan and Cita, 1978; Tibor et al., 1992).

Three drill sites were cored and logged on the Eratosthenes Seamount in the course of Ocean Drilling Program (ODP) Leg 160, with the objective of determining the sedimentary and structural nature of the pre-Pliocene-Quaternary material as a clue to the tectonic evolution of the seamount (Robertson and Shipboard Scientific Party, 1996a; Robertson and Shipboard Scientific Party, 1996b). Sites 966, 965, and 967 (Table 1; Fig. 1) were drilled in a transect from the northern summit plateau to the northern base of the edifice to determine spatial as well as temporal variability of the penetrated sediment cover. Core recovery was poor in the logged intervals at all three sites, so downhole logs were particularly valuable for reconstructing the lithostratigraphy. Recovered sediments provided only intermittent calibration for the logs, because the limited recovery supplied only sparse information about the gross physical properties, cyclicity, and sedimentary structures of the formations.

\section{METHODS}

To obtain a more detailed reconstruction of the sedimentary sequence at each drill site, we identified and refined the lithostratigraphic units based on logs, calibrated with information from cores. Core recovery averaged only $22 \%$ at Hole $966 \mathrm{~F}, 17 \%$ for Hole $965 \mathrm{~A}$, and $14.8 \%$ for Hole $967 \mathrm{E}$ (although recovery in individual cores varied from 0 to $80 \%$; Emeis, Robertson, Richter, et al., 1996). Logs thus give an efficient and reliable means of pinpointing unit boundaries and unconformities, as well as detecting trends within units. Core descriptions and thin sections provided detailed visual information about the rock type and facies. X-ray diffraction and U-Th analyses were conducted to determine mineralogy and chemistry of individual samples, to be compared with log responses and lithologic proxies.

Formation MicroScanner (FMS) and standard wireline logs underwent routine processing to remove borehole environment and fluid effects and were edited to remove spurious data. All logs underwent a constant depth shift relative to the reference datum (seafloor). 
Figure 1. Location of Sites 965, 966, and 967 on the Eratosthenes Seamount. Contour interval is $50 \mathrm{~m}$ (map from Hall et al., 1994).

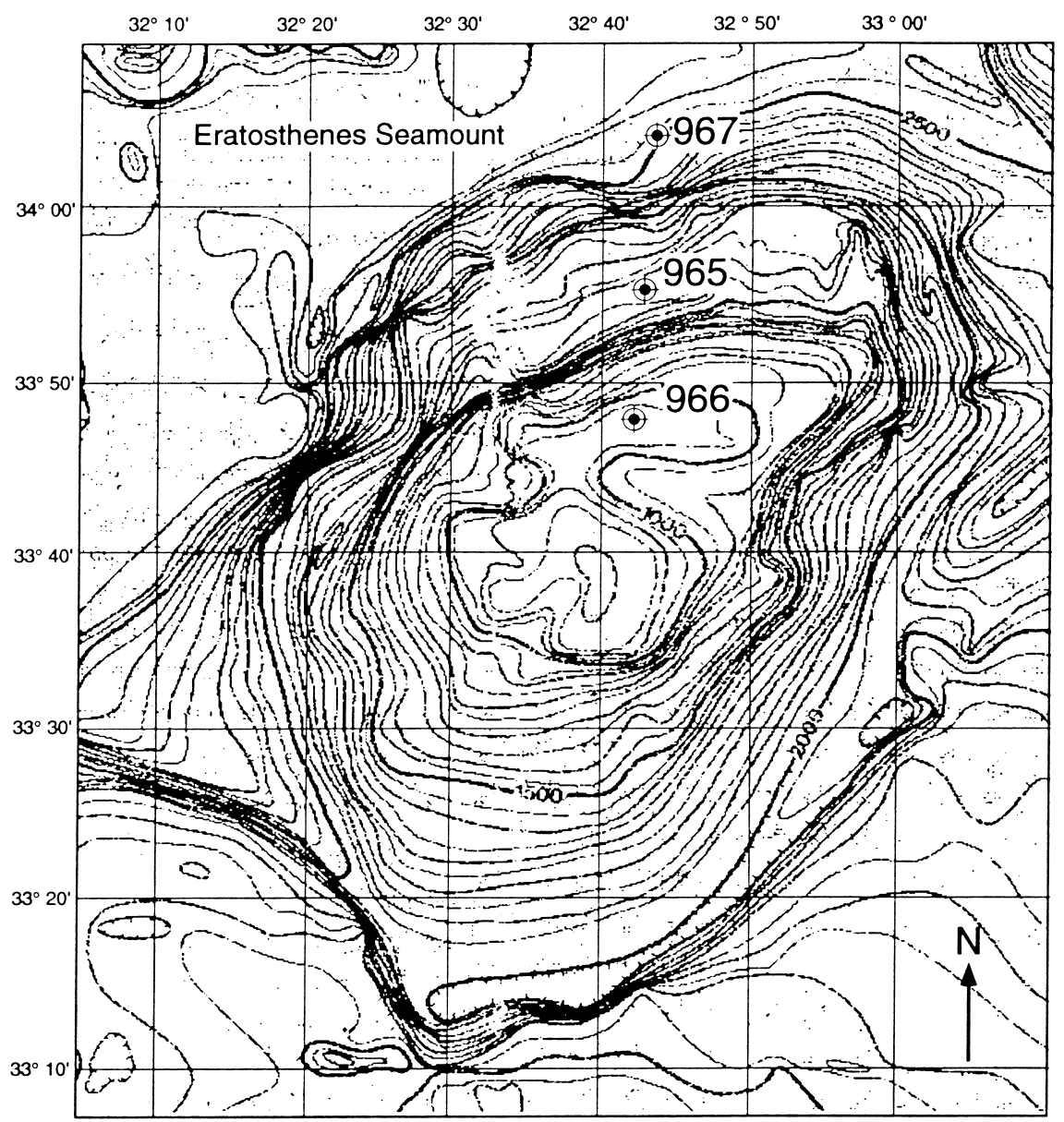

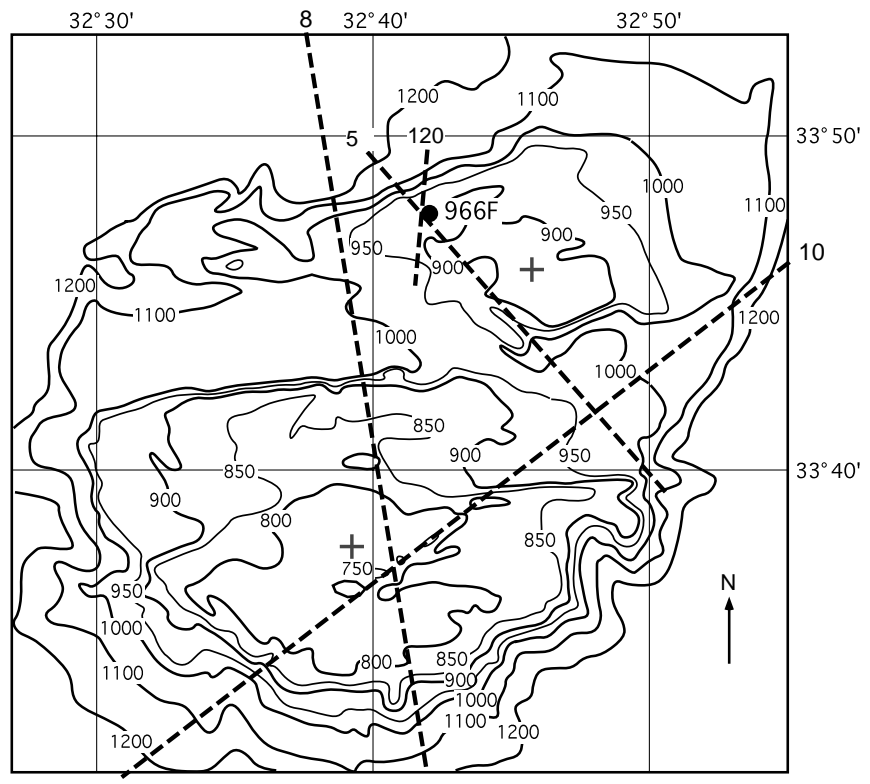

Figure 2. Detailed 50-m contours of the summit of Eratosthenes Seamount showing the location of Site 966 and seismic profiles illustrated in Figures 3, 4,7 . Note that the summit sits at two levels and has numerous small spires and depressions (adapted from Krasheninnikov et al., 1994).
Accelerometer corrections were applied to the FMS images to correct for the tool's varying speed. Standard logs were interactively depthshifted with reference to the gamma-ray (NGT) log from the quad combination tool string. Bedding orientations were calculated using an interactive dip picking procedure (method described in Serra, 1989). Overall log quality was good except for some intervals where the caliper log indicated washed-out hole conditions (Emeis, Robertson, Richter, et al., 1996). Details of the shore-based log processing are discussed in Emeis, Robertson, Richter, et al. (1996).

Thin sections were prepared from samples from all three Eratosthenes sites, descriptions of which appear in Tables 2, 3, and 4 along with descriptions of shipboard thin sections. Thin sections were stained with alizarin red to distinguish calcite from dolomite. Dunham's carbonate classification scheme was used to convey interpreted depositional environments rather than diagenetic features (degree of development of carbonate spar, micritization, and so on; Dunham, 1962). Microfacies descriptions based on thin section analyses were then compared with visual core descriptions and core photographs to assess the degree to which percentages estimated from thin section could be up-scaled to the core scale. We found that in very heterogeneous lithologies, such as reef facies, individual thin section descriptions commonly disagreed with macroscale descriptions of cores.

Analyses by XRD were made to confirm thin-section mineral identifications. Both the log data and the rocks' appearance suggested a very clean carbonate composition, with little terrigenous material. The XRD analysis showed that the dominant minerals in Hole 966 F were calcite and $\mathrm{Fe}$-dolomite (ankerite), nearly excluding other minerals. Calcite was dominant in all analyzed Hole 967E samples. 


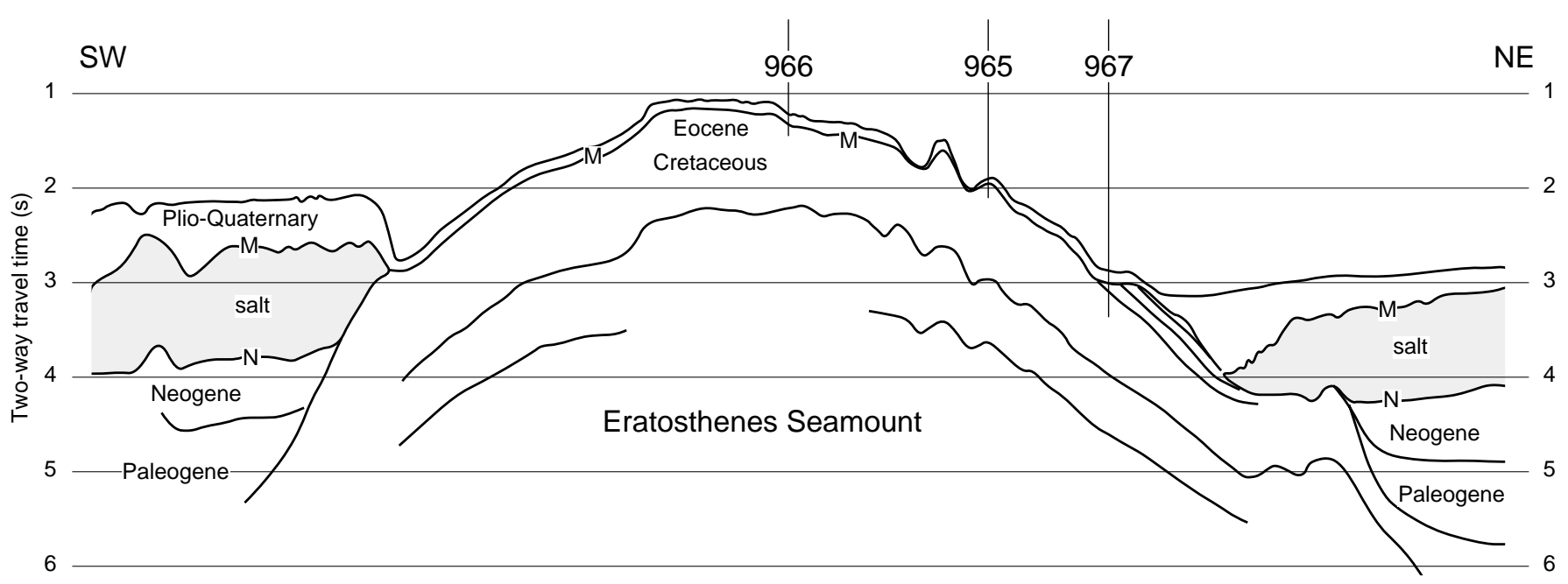

Figure 3. Interpreted multichannel seismic profile 10 (see Fig. 2 for location) extending across the Eratosthenes Seamount, illustrating the thick accumulations of Neogene and Paleogene sediments in the adjacent basin. The drill sites are projected onto the profile. Note that the seamount comprises mainly Cretaceous and older strata.

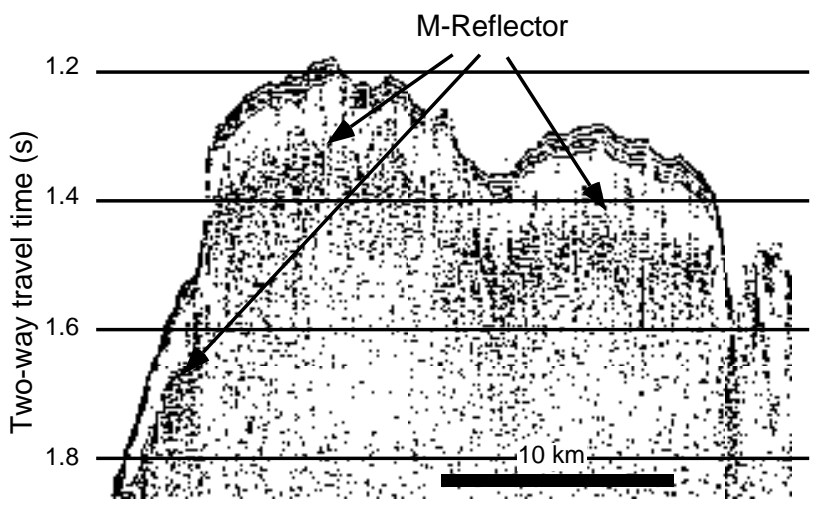

NW

SE

Figure 4. Reflection profile 5 across the summit of Eratosthenes Seamount illustrating the highly reverberant nature of the $\mathrm{M}$ reflector (adapted from Krasheninnikov et al., 1994).

Table 1. Location, depth, and average core recovery for holes logged on the Eratosthenes Seamount.

\begin{tabular}{|c|c|c|c|c|c|}
\hline $\begin{array}{l}\text { Hole } \\
\text { logged }\end{array}$ & Latitude & Longitude & $\begin{array}{l}\text { Water depth } \\
\text { (mbsf) }\end{array}$ & $\begin{array}{c}\text { Depth of } \\
\text { penetration }\end{array}$ & $\begin{array}{c}\text { Total core } \\
\text { recovered }(\mathrm{m})\end{array}$ \\
\hline 965 & $33^{\circ} 55.080 \AA \mathrm{N}$ & $32^{\circ} 42.785^{\prime} \mathrm{E}$ & 1506.6 & 250.4 & 42.8 \\
\hline 966 & $33^{\circ} 47.858 \AA \mathrm{N}$ & $32^{\circ} 42.093^{\prime} \mathrm{E}$ & 926.3 & 356 & 65.9 \\
\hline 967 & $34^{\circ} 04.106^{\prime} \mathrm{N}$ & $32^{\circ} 43.535^{\prime} \mathrm{E}$ & 2552.7 & 600.3 & 72.3 \\
\hline
\end{tabular}

\section{RESULTS}

\section{Lithology from Eratosthenes Seamount}

The three sites drilled on Eratosthenes Seamount give evidence of depositional environments over a wide range of basin depths. Sediments are predominantly carbonate because of the isolation of the high-standing seamount from terrigenous input via turbidity currents. Diagenesis ranges from virtually zero in the nannofossil oozes to extreme in brecciated limestone showing strong stylolitic dissolution.
There is some uncertainty in the age-equivalence between the three sites, resulting from both the presence of three major unconformities and to the lack of age-diagnostic fauna in the shallow-water platform-type limestone facies. However, the succession of facies as well as biostratigraphic and sequence stratigraphic constraints on the timing of certain easily identifiable events (such the Messinian desiccation) in the sections provide a coherent portrait of the evolution of the depositional environments since the early to late Cretaceous.

Electrofacies determined from the downhole logs reflect the main sedimentary events seen in the recovered cores. Descriptions of the logging units can also be found in Emeis, Robertson, Richter, et al. (1996).

\section{Site 966: Seamount Summit}

Three lithostratigraphic units are recognized in the pre-PlioceneQuaternary section at Site 966 on the basis of the visual core descriptions, thin sections (Fig. 5; Table 2), logs (Fig. 6), and seismic reflection profiles (Fig. 7; Table 5). These units can be further subdivided on the basis of textural differences in the FMS images and changes in other log responses discussed below.

Lithostratigraphic Unit I ( 0 to $69 \mathrm{mbsf}$ ) comprises unconsolidated and bioturbated Pliocene-Quaternary-aged nannofossil ooze with numerous thin sapropels. This unit was logged through the drill pipe (the bottom-hole assembly was positioned at $\sim 70 \mathrm{mbsf}$ ), and thus $\log$ signals (e.g., gamma ray) are attenuated.

Lithostratigraphic Unit II (69 to 114 mbsf), directly underlying the Pliocene sapropel-bearing oozes, is an indurated matrix-supported carbonate breccia with clasts up to $4 \mathrm{~cm}$ (Fig. 8). This unit appears in the FMS images as a low-resistivity interval lacking prominent bedding structures. Gamma-ray logs indicate the presence of small amounts of clay, suggested by small peaks in the potassium and thorium spectral logs. A distorted organic-rich bed in Section $966 \mathrm{~F}-4 \mathrm{R}$ 1 seems to correlate with an isolated peak in uranium seen at about $89.5 \mathrm{mbsf}$ in the logs. The amount of uranium increases abruptly again from fairly low background values at about $100 \mathrm{mbsf}$. Other logs do not show a significant deflection at this level. There is an overall increase in the concentration of clasts in the breccia going downward through the unit, with a marked increase in the number of clasts occurring below 93 mbsf. The higher uranium log values are loosely correlated with this increase in the number of clasts, and may 
Table 2. Thin-section descriptions for Site 966.

\begin{tabular}{|c|c|c|c|c|c|c|}
\hline $\begin{array}{l}\text { Sample } \\
\text { number }\end{array}$ & Core, section & $\begin{array}{l}\text { Centimeters } \\
\text { in core }\end{array}$ & $\begin{array}{l}\text { Depth } \\
\text { (mbsf) }\end{array}$ & Rock type & Bioclasts & Description \\
\hline 1 & 6R-CC & $10-19$ & 105.9 & Bioclastic wackestone & & \\
\hline 2 & $* 6 \mathrm{R}-\mathrm{CC}$ & $16-22$ & 105.96 & Mudstone & Rare foraminifers, possible ostracodes & Mottled texture, vuggy porosity, some terrigenous grains \\
\hline 3 & $7 \mathrm{R}-1$ & $10-12$ & 115.5 & Bioclastic grainstone & Foraminifers, molluscs & Moldic porosity after molluscs \\
\hline 4 & $* 7 \mathrm{R}-1$ & $12-14$ & 115.52 & Bioclastic packstone & Foraminifers & Very high moldic porosity after molluscs \\
\hline 5 & $8 \mathrm{R}-1$ & $4-8$ & 125.04 & Bioclastic grainstone & Foraminifers & Moldic porosity after foraminifers \\
\hline 6 & $8 \mathrm{R}-1$ & $8-12$ & 125.08 & Bioclastic packstone & Foraminifers & Recrystallized \\
\hline 7 & $* 8 \mathrm{R}-1$ & $51-56$ & 125.51 & Bioclastic packstone & Foraminifers, algae, mollusc & Partial moldic porosity after algae, few terrigenous grains \\
\hline 8 & $8 \mathrm{R}-1$ & $91-99$ & 125.91 & Bioclastic packstone & Benthic foraminifers, molluscs, echinoids & Some terrigenous material \\
\hline 9 & * $9 \mathrm{R}-1$ & $5-9$ & 134.65 & Bioclastic grainstone/packstone & $\begin{array}{l}\text { High-diversity moldic porosity, voids partially filled with quartz cement }\end{array}$ & Some tentigenous materiar \\
\hline 10 & $* 10 \mathrm{R}-1$ & $44-49$ & 144.64 & Bioclastic grainstone/packstone & Algae, foraminifers, molluses, gastropods & \\
\hline 11 & $* 10 \mathrm{R}-2$ & $8-13$ & 145.78 & Bioclastic packstone & Benthic foraminifers, algae, molluscs & Vuggy porosity, partially recrystallized \\
\hline 12 & $10 \mathrm{R}-2$ & $76-81$ & 146.46 & Algal packstone/grainstone & Algae, molluscs, foraminifers, echinoderm & 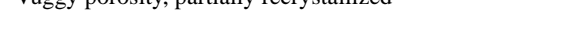 \\
\hline 13 & $11 \mathrm{R}-1$ & $24-28$ & 154.04 & Algal packstone & Algae & \\
\hline 14 & 11R-1 & $60-65$ & 154.4 & Bioclastic rudstone & Coral, algae, foraminifers, molluscs & \\
\hline 15 & 11R-1 & $65-70$ & 154.45 & Recrystallized limestone & & Totally recrystallized, rice grain shape crystals \\
\hline 16 & $* 11 \mathrm{R}-1$ & $127-132$ & & Bioclastic packstone & Foraminifers & Patchy recrystallization \\
\hline 17 & $11 \mathrm{R}-2$ & $4-10$ & 155.34 & Coralgal grainstone/rudstone & Coral, algae, minor pore space & \\
\hline 18 & $11 \mathrm{R}-2$ & $9-16$ & 155.41 & Algal grainstone/rudstone & Coral, algae & \\
\hline $\begin{array}{l}10 \\
19\end{array}$ & $11 \mathrm{R}-2$ & $45-51$ & 155.75 & Algal grainstone/packstone & Algae & Recrystallized \\
\hline 20 & $11 \mathrm{R}-2$ & $85-91$ & 156.15 & Coralgal packstone/rudstone & Coral, algae & Nectystanzed \\
\hline 21 & $* 11 \mathrm{R}-2$ & $\begin{array}{l}0.41 \\
39-45\end{array}$ & 155.69 & Coral packstone/rudstone & Coral, algae, diverse fauna & \\
\hline 22 & $* 11 \mathrm{R}-3$ & $71-75$ & 157.71 & Coralgal packstone/rudstone & Coral, algae & \\
\hline 23 & $11 \mathrm{R}-3$ & $97-104$ & 157.77 & Recrystallized limestone & Coral & \\
\hline 24 & $12 \mathrm{R}-1$ & $13-20$ & 163.63 & Bioclastic packstone/rudstone & Coral, mollusc, algae, benthic foraminifers & \\
\hline 25 & $12 \mathrm{R}-1$ & $13-20$ & 163.63 & Bioclastic floatstone & & \\
\hline 26 & $* 12 \mathrm{R}-1$ & $115-120$ & 164.65 & Bioclastic packstone & & Dolomite rhombs in matrix \\
\hline 27 & $* 12 \mathrm{R}-2$ & $45-51$ & 165.45 & Mudstone & & \\
\hline 28 & $* 13 \mathrm{R}-1$ & $92-95$ & 174.02 & Bioclastic wackestone/floatstone & Algae, echinoids, diverse fauna & \\
\hline 29 & $13 \mathrm{R}-1$ & $126-133$ & 174.36 & Bioclastic wackestone/floatstone & Algae & \\
\hline 30 & $14 \mathrm{R}-1$ & $22-27$ & 182.92 & Algal wackestone & Algae & \\
\hline 31 & $* 14 \mathrm{R}-1$ & $28-32$ & 182.98 & Algal packstone/grainstone & Algae & Moldic porosity after algae \\
\hline 32 & $* 14 \mathrm{R}-2$ & $5-9$ & 184.25 & Algal wackestone & Algae & Norotic porosity arter argae \\
\hline 33 & $* 15 \mathrm{R}-1$ & $21-25$ & 192.63 & Algal wackestone & $\begin{array}{l}\text { Agae } \\
\text { Algae }\end{array}$ & \\
\hline 34 & $15 \mathrm{R}-1$ & $62-65$ & 193.02 & Bioclastic wackestone & Algae & \\
\hline 35 & $* 15 \mathrm{R}-2$ & $45-49$ & 194.35 & Algal wackestone & Algae & Moldic porosity \\
\hline 36 & $* 16 \mathrm{R}-1$ & $65-69$ & 202.65 & Algal wackestone & & \\
\hline 37 & $16 \mathrm{R}-1$ & $86-91$ & 202.86 & Algal wackestone & Algae & \\
\hline 38 & $* 16 \mathrm{R}-2$ & $35-40$ & 203.85 & Algal packstone & Algae & \\
\hline 39 & $* 16 \mathrm{R}-3$ & 107-107 & 206.07 & Algal packstone/rudstone & Algae & \\
\hline 40 & $* 17 \mathrm{R}-1$ & $73-76$ & 212.23 & Algal wackestone & Algae & Moldic porosity after algae \\
\hline 41 & $* 17 \mathrm{R}-2$ & $127-132$ & 214.27 & Algal wackestone & Algae & \\
\hline 42 & $* 17 \mathrm{R}-3$ & $116-118$ & 215.76 & Algal wackestone & Algae & \\
\hline 43 & $17 \mathrm{R}-4$ & $8-11$ & 216.03 & Bioclastic wackestone & Algae & \\
\hline 44 & $* 17 \mathrm{R}-4$ & $35-39$ & 216.27 & Algal wackestone/floatstone & Algae & Moldic porosity after algal filaments \\
\hline 45 & $* 18 \mathrm{R}-1$ & $110-113$ & 222.4 & Algal wackestone & $\begin{array}{l}\text { Agae } \\
\text { Algae }\end{array}$ & Miorace porosty anter algar mantents \\
\hline 46 & $* 18 \mathrm{R}-2$ & $85-89$ & 223.65 & Algal wackestone & Algae & Moldic porosity after algal filaments \\
\hline 47 & $* 19 \mathrm{R}-1$ & $120-124$ & 232.2 & Bioclastic floatstone & Algae, molluscs, foraminifers, bryozoans & \\
\hline 48 & $19 \mathrm{R}-2$ & $35-39$ & 232.73 & Algal packstone & Algae, benthic foraminifers, bryozoans & \\
\hline 49 & $* 19 \mathrm{R}-2$ & $139-143$ & 233.48 & Bioclastic wackestone & Benthic foraminifers, algae & Vuggy porosity \\
\hline 50 & $* 19 \mathrm{R}-3$ & $89-92$ & 234.89 & Bioclastic packstone & $\begin{array}{l}\text { Foraminifers, algae } \\
\text { Fas }\end{array}$ & vazgy porosity \\
\hline 51 & $* 20 \mathrm{R}-2$ & $5-7$ & 240.65 & Bioclastic wackestone & Planktonic and benthic foraminifers, echinoids & \\
\hline 52 & $21 \mathrm{R}-1$ & $8-11$ & 250.38 & Recrystallized limestone & & \\
\hline 53 & $21 \mathrm{R}-1$ & $29-30$ & 250.59 & Bioclastic wackestone & Foraminifers & \\
\hline 54 & $* 23 \mathrm{R}-1$ & $28-30$ & 269.68 & Foraminifer packstone & Foraminifers, echinoids, bryozoans & \\
\hline 55 & $23 \mathrm{R}-1$ & $28-31$ & 269.68 & Bioclastic grainstone & Bryozoans, foraminifers & \\
\hline 56 & $23 \mathrm{R}-1$ & $38-41$ & 269.78 & Bryozoan grainstone & Bryozoans, foraminifers & \\
\hline 57 & $23 \mathrm{R}-1$ & 63-65 & 270.03 & Bryozoan grainstone & Bryozoans, foraminifers & \\
\hline 58 & $* 25 \mathrm{R}-1$ & $\begin{array}{l}65-05 \\
6-9\end{array}$ & 288.66 & Foraminifer packstone & Planktonic foraminifers, benthic foraminifers, echinoids, bryozoans & \\
\hline 59 & $26 \mathrm{R}-1$ & $9-12$ & 298.39 & Bioclastic packstone/grainstone & Foraminifers, algae, bryozoans, foraminifers & \\
\hline 60 & $* 26 \mathrm{R}-1$ & $15-17$ & 298.45 & Foraminifer packstone & Planktonic foraminifers & \\
\hline 61 & $26 \mathrm{R}-1$ & $44-47$ & 298.74 & Foraminifer wackestone & Planktonic foraminifers & \\
\hline 62 & $26 \mathrm{R}-1$ & $56-61$ & 298.86 & Foraminifer wackestone & Planktonic foraminifers & \\
\hline 63 & $26 \mathrm{R}-3$ & $78-81$ & 301.21 & Foraminifer wackestone & Planktonic foraminifers & \\
\hline 64 & $* 28 \mathrm{R}-1$ & $0-4$ & 327.1 & Foraminifer wackestone & Planktonic foraminifers & \\
\hline 65 & $* 28 \mathrm{R}-6$ & $80-84$ & 327.9 & Foraminifer wackestone & Planktonic foraminifers & \\
\hline
\end{tabular}

Note: $*$ thin sections made postcruise. 
Table 3. Thin-section descriptions for Site 965.

\begin{tabular}{|c|c|c|c|c|c|}
\hline $\begin{array}{l}\text { Sample } \\
\text { number }\end{array}$ & $\begin{array}{l}\text { Core, section, } \\
\text { interval }(\mathrm{cm})\end{array}$ & $\begin{array}{l}\text { Depth } \\
\text { (mbsf) }\end{array}$ & Rock type & Bioclasts & Description \\
\hline 1 & $* 9 X-1,67-74$ & 68.17 & Bioclastic packstone & $\begin{array}{l}\text { Algae, echinoderms, gastropods, benthic } \\
\text { foraminifers }\end{array}$ & Some vugs and moldic porosity \\
\hline 2 & $* 10 \mathrm{X}-1,11-21$ & 77.21 & Bioclastic packstone/grainstone & Algae, benthic foraminifers, bryozoans & High moldic and vuggy porosity \\
\hline 3 & $* 11 \mathrm{X}-1,20-24$ & 87.0 & Grainstone & Bryozoans, ostracodes & Micritized, some spar development \\
\hline 4 & $12 \mathrm{X}-1,29-38$ & 96.69 & $\begin{array}{l}\text { Bioclastic wackestone/ } \\
\text { packstone }\end{array}$ & Sponge spicules & $\begin{array}{l}\text { Highly recrystallized; very high intraparticle } \\
\text { porosity }\end{array}$ \\
\hline 5 & $16 \mathrm{X}-1,12-14$ & 135.22 & Bioclastic packstone & Molluscs & $\begin{array}{l}\text { Diverse faunal assemblage; high intraparticle } \\
\text { porosity }\end{array}$ \\
\hline 6 & $* 17 \mathrm{X}-1,7-12$ & 144.77 & $\begin{array}{l}\text { Bioclastic wackestone/ } \\
\text { packstone }\end{array}$ & Coral, echinoderms, benthic foraminifers, algae & \\
\hline 7 & $* 19 \mathrm{X}-1,27-30$ & 164.17 & Bioclastic packstone/grainstone & Echinoderms, algae, benthic foraminifers & Recrystallized, dolomite rhombs \\
\hline 8 & $* 20 X-1,21-25$ & 173.81 & Bioclastic packstone & $\begin{array}{l}\text { Echinoderms, algae, molluscs, benthic foraminifers, } \\
\text { algae }\end{array}$ & Some moldic porosity \\
\hline 9 & $* 21 X-1,21-23$ & 183.31 & Algal wackestone/floatstone & Algae & Recrystallized, dolomitized \\
\hline 10 & $21 \mathrm{X}-1,39-45$ & 183.49 & Algal wackestone & Algae & Recrystallized; algal fragments appear fractured \\
\hline 11 & $* 22 X-1,6-8$ & 192.66 & Bioclastic packstone & Algae, bryozoans, benthic foraminifers, echinoderms & Recrystallized, dolomitized \\
\hline 12 & $* 23 \mathrm{X}-1,0-8$ & 202.2 & Bioclastic packstone/grainstone & Algae, benthic foraminifers, bryozoans, echinoderms & Recrystallized, dolomitized \\
\hline 13 & $* 24 X-1,0-3$ & 211.9 & Algal wackestone/floatstone & Algae & \\
\hline 14 & $24 X-1,55-61$ & 212.45 & Algal wackestone & Algae & Moldic porosity \\
\hline 15 & $* 25 \mathrm{X}-1,0-6$ & 221.5 & $\begin{array}{l}\text { Bioclastic packstone/ } \\
\text { wackestone }\end{array}$ & Benthic foraminifers, echinoderms & \\
\hline 16 & $* 26 \mathrm{X}-1,110-115$ & 232.2 & Algal floatstone & Algae, benthic foraminifers & Algal balls \\
\hline 17 & $* 26 \mathrm{X}-2,7-12$ & 232.67 & Bioclastic wackestone & Algae, echinoderms & High solution porosity; micritized \\
\hline 18 & $* 27 \mathrm{X}-1,13-16$ & 240.93 & Algal wackestone/floatstone & Algae, echinoderms & Fracture; dolomitized \\
\hline
\end{tabular}

Note: $*=$ thin sections made postcruise.

be a result of the inclusion of material derived from the underlying unit, which is relatively uranium-rich. Alternatively the rather abrupt increase in log uranium values at $\sim 100$ mbsf may represent a chemical front formed as the result of migration of uranium-rich fluids during diagenesis.

Lithostratigraphic Unit III (114 to $300 \mathrm{mbsf}$ ) is an indurated limestone. Although there are no age-diagnostic fauna within this unit, it is assumed to be late Miocene (Tortonian) on the basis of one strontium date (E. Frankel, unpubl. data) and its similarity to shallowwater carbonates of known age exposed on Cyprus. The contact between this unit and the overlying breccia appears as a sharp, subhorizontal contact in the FMS image at 114 mbsf (Fig. 9). The transition between the two units is also apparent from an increase in resistivity and a decrease in neutron porosity, which are both directly dependent on the amount of water in the pore space of the formation. Thin sections from Site 966 (Plate 1, figs.1-6) reveal coralgal facies from 165 to 240 mbsf overlying a markedly different facies with abundant bryozoans, but lacking photosynthetic fauna (240 to $300 \mathrm{mbsf}$ ).

Subunit IIIA (114 to $240 \mathrm{mbsf}$ ) exhibits a high degree of variability in facies both in the log responses and in the materials recovered in the cores. Well-bedded grainstone (Fig. 10) and chaotic floatstone (Fig. 11) are both present. All recovered lithologies are representative of a reef to lagoonal environment (Shipboard Scientific Party, 1996b). Uranium computed from spectral gamma-ray logs shows variability at the meter scale in Subunit IIIA. This unit also shows high variability in porosity (both neutron porosity in logs and porosity estimated in thin sections) and resistivity. Much of the porosity occurs as molds and vugs (Plate 1, fig. 1), indicating corrosive fluid flow typical of meteoric diagenesis. Uranium is very mobile under oxidizing pore water conditions, and it is possible that the uranium signature seen in the logs and in the Inductively Coupled Plasma Mass Spectrometer (ICPMS) measurements is the result of post-depositional processes and not related to facies other than in terms of facies porosity. On the other hand, ICPMS analysis of individual samples that could be compared to thin sections of the same samples did seem to show some loose correlation between the abundance of red algae and the uranium content (Plate 1, fig. 3). Red algae can produce locally reducing conditions in the depositional environment that favors the deposition of uranium from seawater (Ogg et al., 1995). However, the amount of uranium present (greater than $8 \mathrm{ppm}$ in some cases) is difficult to explain by this process alone. It also seems un- likely that the uranium is a result of an abundance of organic matter in these rocks, since they have undergone substantial recrystallization and dolomitization in some cases. In addition, the uranium signature for the high organic content sapropels in Core $4 \mathrm{R}$ is not as high as it is in intervals where there is no dark color associated with the rock, and no organic detritus is visible in this section.

Subunit IIIB (240 to $300 \mathrm{mbsf}$ ) is characterized by overall very low gamma-ray signature (about $1 \mathrm{ppm} \mathrm{U}$ ), lower porosities relative to the overlying unit, and fairly low resistivity. The hole conditions in this interval, however, are quite poor, so FMS images, porosity, and density logs are not reliable. However, thin-section data indicate lower porosities, without the pervasive development of moldic and vuggy porosities seen in Subunit IIA. In addition, thin sections show no unequivocally shallow-water fauna (algae and coral), although diverse faunal assemblages including benthic and planktonic foraminifers, echinoderms, and bryozoans are present throughout the section (Plate 1, figs. 6, 7). Fractures are apparent both in thin section and in the FMS images, despite poor image quality.

The lowermost unit in this hole, lithostratigraphic Unit IV (300 to $356 \mathrm{mbsf}$ ), is a burrowed, fairly homogeneous, planktonic foraminifer-rich carbonate with very sharply defined, resistive interbeds and nodules. Foraminifer and nannofossil assemblages indicate a middle Eocene age for deposition of this unit (Premoli Silva et al., Chap. 30, this volume). The unconformable contact between Units III and IV (Fig. 12) is enriched in glauconite, and also contains interclasts and reworked algal fragments.

Coring of Unit IV recovered some chert, though not in proportion to the abundance inferred from the FMS image. Chert is notoriously difficult to recover, and it is likely that the thin chert beds were shattered by the drill bit and washed away with the drilling mud. Zones of more intense drilling deformation in the cores, commonly containing small chert pieces, seem to correspond to intervals with a higher concentration of resistive beds seen in the FMS images, supporting the above conclusions. A major exception to the overall homogeneous nature of lithostratigraphic Unit IV is the presence of a very organic-rich, black micritic limestone just below the unconformable contact with the overlying lower Miocene unit. There is a lower concentration of planktonic forams in this layer than in the rest of the unit, and burrows are flattened. A similar flattening of burrows in organic-rich layers is described in Miocene pelagic carbonates from the Bahama Bank, where it is ascribed to the lack of early cementation, 
Table 4. Thin section descriptions for Site 967.

\begin{tabular}{|c|c|c|c|c|c|}
\hline $\begin{array}{l}\text { Sample } \\
\text { number }\end{array}$ & $\begin{array}{l}\text { Core, section, } \\
\text { interval }(\mathrm{cm})\end{array}$ & $\begin{array}{l}\text { Depth below } \\
\text { seafloor }\end{array}$ & Rock type & Bioclasts & Description \\
\hline 1 & $4 \mathrm{R}-3,33-36$ & 141.46 & Foraminifer wackestone & Planktonic foraminifers & Homogeneous texture, micrite matrix \\
\hline 2 & $4 \mathrm{R}-3,87-90$ & 142 & Foraminifer wackestone & Planktonic foraminifers & Homogeneous texture, micrite matrix, organic material \\
\hline 3 & $* 4 \mathrm{R}-3,97-100$ & 142.1 & Foraminifer wackestone & Planktonic and benthic foraminifers & \\
\hline 4 & $4 \mathrm{R}-3,145-149$ & 142.58 & Foraminifer wackestone & Planktonic foraminifers & Homogeneous texture, micrite matrix, organic material \\
\hline 5 & $5 \mathrm{R}-1,131-133$ & 149.31 & Foraminifer wackestone & Planktonic foraminifers & Homogeneous texture, micrite matrix, microveins \\
\hline 6 & $5 \mathrm{R}-2,13-15$ & 149.57 & Foraminifer wackestone & Planktonic foraminifers & HOHOQ \\
\hline 7 & $5 \mathrm{R}-3,74-79$ & 151.64 & Foraminifer wackestone & Planktonic foraminifers & \\
\hline 8 & $6 \mathrm{R}-1,7-13$ & 157.77 & Foraminifer wackestone & Planktonic foraminifers & \\
\hline 9 & $6 \mathrm{R}-3,13-17$ & 160.56 & Foraminifer wackestone & Planktonic foraminifers & \\
\hline 10 & $6 \mathrm{R}-3,46-51$ & 160.89 & Foraminifer wackestone & Planktonic foraminifers & \\
\hline 11 & $8 \mathrm{R}-1,60-64$ & 177.5 & Foraminifer wackestone & Planktonic foraminifers, some benthic & \\
\hline 12 & $9 \mathrm{R}-1,35-38$ & 186.85 & Foraminifer wackestone & Planktonic foraminifers & \\
\hline 13 & $9 \mathrm{R}-1,69-75$ & 187.19 & Foraminifer wackestone & Planktonic foraminifers & \\
\hline 14 & $* 9 \mathrm{R}-1,100-104$ & 187.5 & Foraminifer wackestone & Planktonic and benthic foraminifers & Burrowed fabric; organic material \\
\hline 15 & $10 \mathrm{R}-3,110-117$ & 200 & Foraminifer wackestone & Planktonic foraminifers, molluscs & \\
\hline 16 & 11R-CC, $15-21$ & 209.1 & Foraminifer wackestone & Planktonic and benthic foraminifers & \\
\hline 17 & $* 12 \mathrm{R}-1,82-86$ & 200.1 & Foraminifer wackestone & Planktonic and benthic foraminifers & \\
\hline 18 & $12 \mathrm{R}-2,31-39$ & 217.21 & Foraminifer wackestone & Planktonic foraminifers & \\
\hline 19 & $12 \mathrm{R}-2,83-87$ & 217.73 & Foraminifer wackestone & Planktonic foraminifers & \\
\hline 20 & $12 \mathrm{R}-3,128-132$ & 219.44 & Foraminifer wackestone & Planktonic and benthic foraminifers & \\
\hline 21 & $13 \mathrm{R}-1,97-100$ & 226.07 & Foraminifer wackestone & Planktonic foraminifers, some benthic, echinoids & \\
\hline 22 & $14 \mathrm{R}-2,60-64$ & 236.8 & Foraminifer wackestone & Planktonic foraminifers & \\
\hline 23 & $14 \mathrm{R}-2,94-98$ & 237.14 & Foraminifer wackestone & Planktonic foraminifers, gastropod & \\
\hline 24 & $15 \mathrm{R}-1,19-24$ & 244.49 & Foraminifer wackestone & Planktonic and benthic foraminifers & \\
\hline 25 & $16 \mathrm{R}-1,0-6$ & 253.9 & Foraminifer wackestone & Planktonic foraminifers, some benthic & \\
\hline 26 & $* 16 \mathrm{R}-1,56-60$ & 254.46 & Wackestone & Planktonic and benthic foraminifers; molluscs & \\
\hline 27 & $* 17 \mathrm{R}-1,34-37$ & 263.84 & Foraminifer wackestone & Planktonic and benthic foraminifers & \\
\hline 28 & $17 \mathrm{R}-1,36-40$ & 263.86 & Foraminifer wackestone & Planktonic foraminifers & \\
\hline 29 & $17 \mathrm{R}-2,50-55$ & 265.4 & Foraminifer wackestone & Planktonic foraminifers & \\
\hline 30 & $18 \mathrm{R}-1,18-20$ & 273.28 & Foraminifer wackestone & Planktonic foraminifers & \\
\hline 31 & $* 18 \mathrm{R}-1,34-37$ & 273.44 & Foraminifer wackestone & Planktonic and benthic foraminifers & Fabric traced by organic streaks \\
\hline 32 & $18 \mathrm{R}-2,24-28$ & 274.62 & Foraminifer wackestone & Planktonic foraminifers & \\
\hline 33 & $19 \mathrm{R}-1,0-6$ & 282.7 & Chert & Planktonic foraminifers & \\
\hline 34 & $20 \mathrm{R}-1,9-15$ & 292.39 & Foraminifer wackestone & Planktonic foraminifers & \\
\hline 35 & $21 \mathrm{R}-1,22-26$ & 302.12 & Foraminifer wackestone & Planktonic foraminifers & \\
\hline 36 & *22R-1, 80-83 & & Foraminifer wackestone & Planktonic foraminifers & \\
\hline 37 & $23 \mathrm{R}-1,1-2$ & 321.21 & Chert & Planktonic foraminifers & \\
\hline 38 & $* 24 \mathrm{R}-1,0-4$ & & Chert & Planktonic foraminifers & Foraminifers appear as ghosts \\
\hline 39 & $* 25 \mathrm{R}-1,87-90$ & 344.3 & Foraminifer wackestone & Planktonic foraminifers & Trace organic material \\
\hline 40 & $25 \mathrm{R}-1,114-119$ & 344.57 & Foraminifer wackestone & Planktonic foraminifers, echinoids, molluscs & \\
\hline 41 & $* 26 \mathrm{R}-1,3-5$ & 350.13 & Bioclastic wackestone & Planktonic foraminifers; molluscs & Glauconite \\
\hline 42 & $26 \mathrm{R}-1,4-7$ & 350.14 & Foraminifer wackestone & Planktonic foraminifers, echinoids & C \\
\hline 43 & $28 \mathrm{R}-1,117-121$ & 370.47 & $\begin{array}{l}\text { Organic-rich foraminifer } \\
\text { wackestone }\end{array}$ & Planktonic foraminifers & \\
\hline 44 & $29 \mathrm{R}-1,140-145$ & 380.2 & Foraminifer wackestone & Planktonic foraminifers, some molluscs & \\
\hline 45 & $29 \mathrm{R}-2,22-27$ & 380.52 & Foraminifer wackestone & Planktonic foraminifers & \\
\hline 46 & $30 \mathrm{R}-1,10-15$ & 388.5 & Mudstone & Few molluscs & \\
\hline 47 & $30 \mathrm{R}-1,15-20$ & 388.55 & Foraminifer wackestone & Planktonic and benthic foraminifers, other & \\
\hline 48 & $30 \mathrm{R}-1,30-34$ & 388.7 & Foraminifer wackestone & Planktonic foraminifers, some molluscs, echinoids & \\
\hline 49 & $30 \mathrm{R}-1,55-59$ & 388.95 & $\begin{array}{l}\text { Organic-rich foraminifer } \\
\text { wackestone }\end{array}$ & Planktonic foraminifers & \\
\hline 50 & *33R-1, 26-29 & & $\begin{array}{l}\text { wackestone } \\
\text { Foraminifer wackestone/packstone }\end{array}$ & & \\
\hline 51 & *34R-1, 11-14 & & Bioclastic wackestone/ packstone & Benthic foraminifers & All grains are micritized; some sparite \\
\hline 52 & $35 \mathrm{R}-1,13-15$ & 436.73 & Foraminifer wackestone & Planktonic foraminifers & \\
\hline 53 & $* 37 \mathrm{R}-1,0-3$ & 455.9 & Bioclastic packstone & Benthic foraminifers & Silica spherules; grains are micritized; pressure solution grain boundaries; high porosity \\
\hline 54 & $37 \mathrm{R}-1,0-5$ & 455.9 & Grainstone & Benthic foraminifers & \\
\hline 55 & $37 \mathrm{R}-1,5-9$ & 455.95 & Grainstone & Benthic foraminifers & \\
\hline 56 & $37 \mathrm{R}-1,9-13$ & 455.99 & Grainstone & & \\
\hline 57 & $39 \mathrm{R}-1,4-10$ & 475.14 & Wackestone & Foraminifers and molluscs & \\
\hline 58 & $* 39 \mathrm{R}-1,10-12$ & & Bioclastic wackestone & Benthic foraminifers & Stylolites; solution porosity \\
\hline 59 & $41 \mathrm{R}-1,0-5$ & 494.4 & Wackestone & Foraminifers & \\
\hline 60 & $41 \mathrm{R}-1$ & 494.52 & Wackestone/ floatstone & Foraminifers & \\
\hline 61 & 41R-1, & 495.3 & Wackestone & Foraminifers & \\
\hline 62 & $42 \mathrm{R}-1$ & 504.01 & Wackestone & Foraminifers, molluscs & \\
\hline 63 & $44 \mathrm{R}-1$, & 523.21 & Chert & & \\
\hline
\end{tabular}


Table 5. Boundary of the lithostratigraphic units of Hole $966 \mathrm{~F}$ referenced to sub-bottom two-way traveltime.

\begin{tabular}{crrrrrr}
\hline $\begin{array}{c}\text { Lithostratigraphic } \\
\text { unit }\end{array}$ & $\begin{array}{c}\text { Top } \\
(\mathrm{m})\end{array}$ & $\begin{array}{c}\text { Bottom } \\
(\mathrm{m})\end{array}$ & $\begin{array}{c}\text { Thickness } \\
(\mathrm{m})\end{array}$ & $\begin{array}{c}\text { Interval velocity } \\
(\mathrm{km} / \mathrm{s})\end{array}$ & $\begin{array}{c}\text { Thickness } \\
(\mathrm{ms})\end{array}$ & $\begin{array}{c}\text { Bottom } \\
(\mathrm{ms})\end{array}$ \\
\hline I & 0 & 69 & 69 & 1.7 & 81.2 & 81.2 \\
II & 69 & 114 & 45 & 1.8 & 50.0 & 131.2 \\
III & 114 & 220 & 106 & 2.5 & 84.8 & 216.0 \\
III & 220 & 250 & 30 & 3.2 & 18.8 & 234.7 \\
III & 250 & 300 & 50 & 3.5 & 28.6 & 263.3 \\
IV & 300 & 356 & 56 & 3.1 & 36.1 & 299.4
\end{tabular}

possibly related to the decay of the organic matter in the sediments which increases $\mathrm{CO}_{2}$ content of the pore waters, making them more corrosive. Foraminifer tests and burrows in the less organic-rich, deeper interval of this unit do not show evidence of much compaction.

The organic-rich layer at the top of Unit IV corresponds to a large spike in the uranium $\log$ (about $8 \mathrm{ppm}$ ). Core uranium measurements confirm that the black limestone has a higher uranium content than the paler limestone. This may be a result of enhanced uranium deposition in locally reducing conditions caused by the oxidation of large amounts of organic matter, or simply uranium adsorbed onto organic particles during deposition. A thinner organic rich layer in the same core probably correlates with the lower uranium spike. Uranium values from the pale background sediments are much lower (1-2 ppm). The high uranium contents below the Unit III/IV unconformity might also indicate that the unconformity was a hardground of very low to nonexistent deposition.

\section{Site 965: Seamount Flank}

Site 965 was drilled in $1506.6 \mathrm{~m}$ water depth on the northern slope of Eratosthenes Seamount (Fig. 1; Table 1). Shipboard seismic profiles showed that the site is located on a north-south trending, steepsided promontory. The sapropel-bearing Pliocene-Quaternary ooze was thin at this site, offering a window into the underlying lithologies. Three main lithologic units were recovered at this site (Fig. 13; Table 3).

Lithostratigraphic Unit II ( 23 to $29 \mathrm{mbsf}$ ), directly underlying the Pliocene-Quaternary oozes, is a calcareous clay with angular clasts of carbonate up to $1 \mathrm{~cm}$ in diameter. The top of this unit is marked by the presence of a dark layer underlain by a $20 \mathrm{~cm}$-thick layer of carbonate nodules, interpreted as a paleosol. Abrupt deflections in core density, $P$-wave velocity, and natural gamma-ray measurements between 23 and 24 mbsf (Fig. 13) suggest a significant change in sediment properties at this level, which corresponds to approximately the top of the paleosol.

Lithostratigraphic Unit III (29 mbsf to bottom of hole), underlying the paleosol, comprises shallow water carbonates, with facies similar to those recovered in Hole 966F. Two strontium dates indicate a Tortonian age (Frankel et al., unpubl. data). Algae dominate the bioclasts, with additional common benthic foraminifers, coral, mollusks, and echinoderms. Coral fragments appear to be encrusting Porites sp. (Emeis, Robertson, Richter, et al., 1996). This limestone has undergone pervasive recrystallization, though not to the extent that the original depositional fabric of the rock is obscured. A transition from grainstones toward the top of the unit to more muddy wackestones at the bottom suggests an increase in energy upward in the unit, possibly associated with upward shallowing. Fractures also appear at the bottom of the unit.

The coralgal facies represented at Site 965 may be evidence of reef formation at this site during the Messinian. Several authors (Esteban, 1980; Pomar, 1991) have noted the predominance of Porites sp. in Messinian reefs of the Western Mediterranean. 


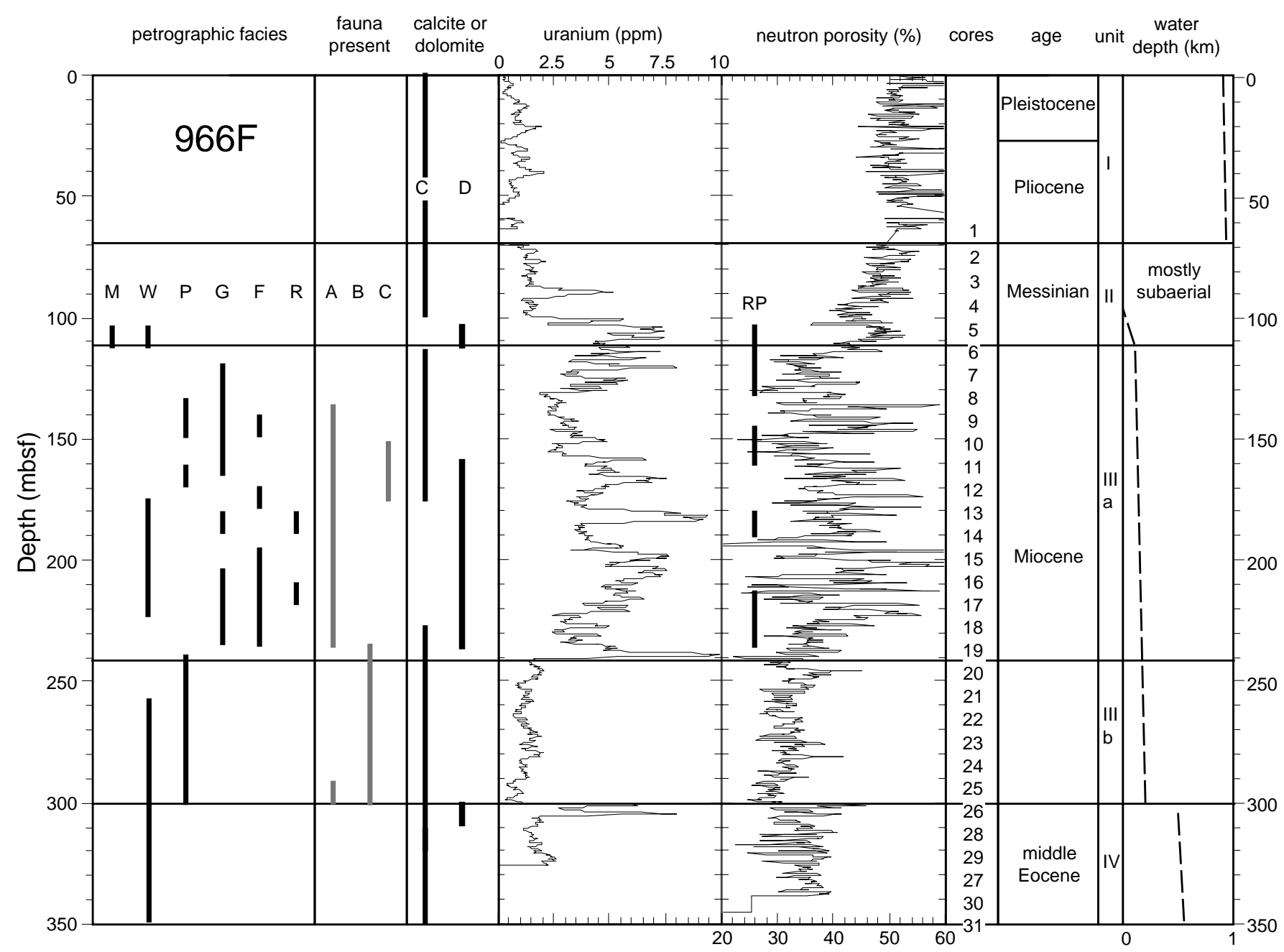

Figure 5. The interpreted petrographic facies $(\mathrm{M}=$ mudstone, $\mathrm{W}=$ wackestone, $\mathrm{P}=$ packstone, $\mathrm{G}=$ grainstone, $\mathrm{F}=$ floatstone, $\mathrm{R}=$ rudstone $)$, bioclasts $(\mathrm{A}=$ algae, $\mathrm{B}=$ bryozoans, $\mathrm{C}=$ coral $)$, mineralogy $(\mathrm{C}=$ calcite, $\mathrm{D}=$ dolomite $)$, porosity $(\mathrm{RP}=$ remolded porosity present $)$, and logs from Site 966 from the northern summit of Eratosthenes Seamount. Water depth is inferred from depositional facies.

The log responses in the shallow-water carbonates (lithostratigraphic Unit III) of Site 965 differ significantly from those in the similar unit from Site 966 (Unit IIIA). Logging covers only Unit III, with the exception of the gamma-ray logs which can measure through pipe at the top of the hole. Resistivity, density, and neutron porosity in particular show less variability, especially in the upper part of the logged interval (above $200 \mathrm{mbsf}$ ). This may be due to less diagenetic dissolution porosity and recementation at the deeper flank site than at the summit. Thin section analyses indicate that average grain size at Site 965 is less than that at Site 966, which suggests that the amount of dissolution is at least partly controlled by the amount of primary porosity. In samples with large grain size from Site 965 (e.g., bioclastic grainstones) there is pervasive development of moldic porosity similar to that seen at Site 966. The gamma-ray logs show much lower values than those within the Miocene shallow-water carbonates of Site 966 . Very high-resistivity beds toward the bottom of the hole (below $200 \mathrm{mbsf}$ ), which correspond to low neutron porosity values and high densities, suggest highly cemented beds. High photoelectric factor values ( 7 to 9 barns $/ \mathrm{e}^{-}$) indicate the presence of a mineral other than calcium carbonate or dolomite, possibly ankerite (Shipboard Scientific Party, 1996a). X-ray diffraction analysis at Site 966 showed ankerite (or high Fe dolomite) to be the dominant mineral in some intervals (Shipboard Scientific Party, 1996a). However, no XRD analysis was done for samples from Site 965.

\section{Site 967: Base of Seamount}

Site 967 was drilled in $2552.7 \mathrm{~m}$ of water at the base of the north flank of Eratosthenes Seamount (Fig. 1; Table 1). The site is located on a small east-west-trending ridge thought to be an upthrust structure related to compressional subduction processes (Shipboard Scientific Party, 1996c; Robertson et al., 1996a).

Lithostratigraphic Unit I (0 to 119 mbsf, Hole 967A; Fig. 14) comprises nannofossil oozes with interbedded sapropels. The foraminiferal assemblage indicates a bathyal environment of about $2 \mathrm{~km}$ depth (M.B. Cita, pers. comm., 1997). The top of lithostratigraphic Unit II contains interbedded nannofossil ooze and clay with fragile ostracode carapaces indicative of the Lago Mare facies (119 to 131.7 mbsf; Cita, 1982; Cita et al., 1978), as well as the absence of reworking (Premoli Silva et al., Chap. 30, this volume). Sharply defined major peaks in the gamma-ray, resistivity, and sonic logs within Unit II indicate the presence of a 5-m-thick evaporite below the Lago Mare 


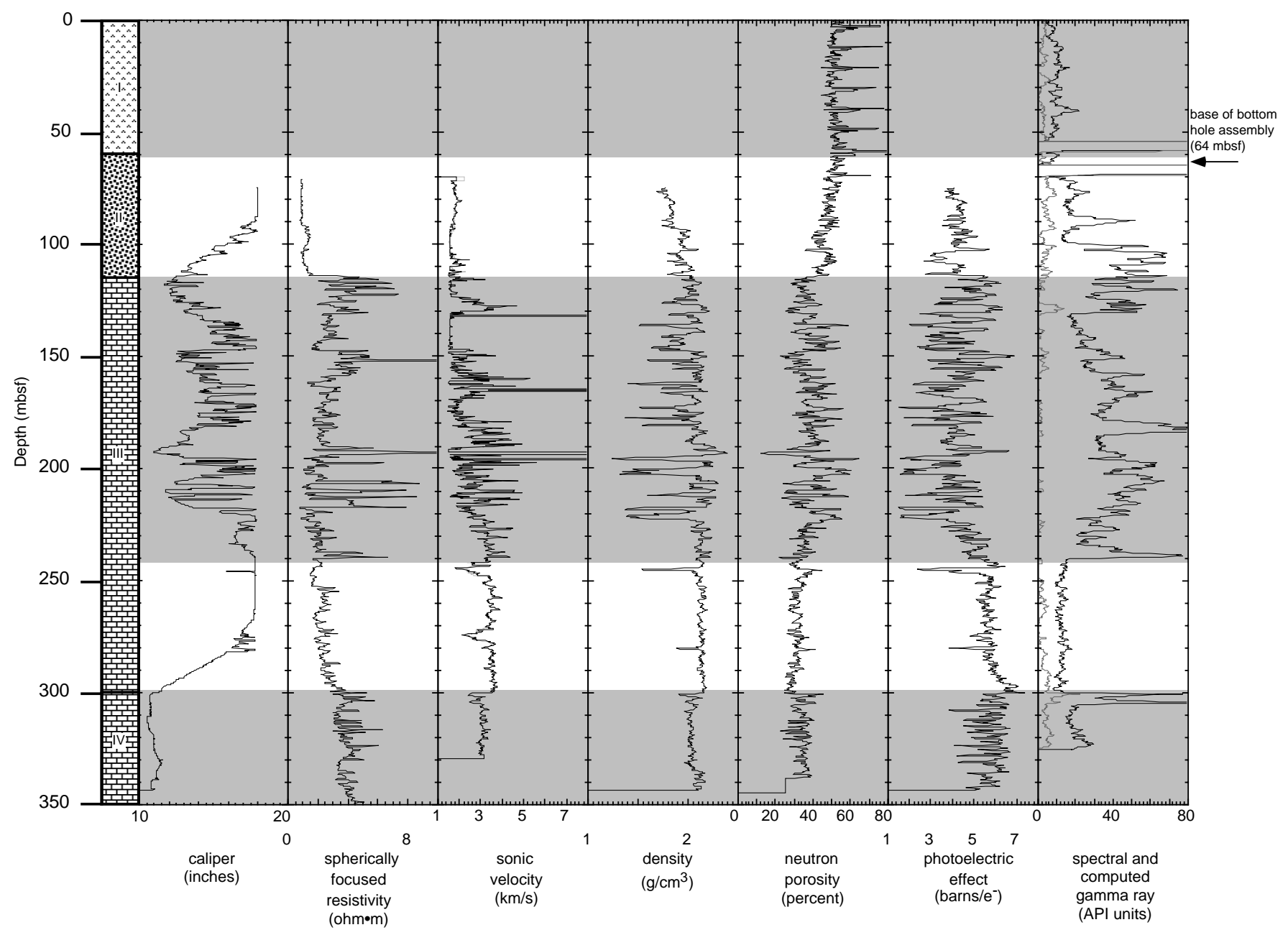

Figure 6. Summary of logs from Hole 966F. Column on left shows the four major lithostratigraphic units described in the text.

sediments, composed of gypsum based on geochemical analysis of pore waters from the overlying unit and values from geochemical logs. This evaporite is evident in the FMS imagery as a zone of high resistivity, and in the standard logs as a zone of high bulk density, high compressional-wave velocity, and low gamma-ray (Figs. 15 and 16).

The contact below the evaporite and the Lago Mare subunits is sharp though irregular. The bottom of lithostratigraphic Unit II comprises a foraminifer nannofossil chalk with interbeds of silty calcareous ooze. This latter interval contains a mixed middle Eocene, Oligocene, and upper Miocene foraminiferal assemblage, as well as glauconite and some terrigenous grains, and is likely the equivalent of the Messinian clastic deposits of the deep Mediterranean basins. Unit II as a whole is assigned to the younger part of the Messinian between 5.8 and 5.32 Ma when the Mediterranean was drawn down with respect to the Atlantic Ocean.

Underlying Unit II is an intensely burrowed foraminifer-rich chalk belonging to lithostratigraphic Unit III (133 to $427 \mathrm{mbsf}$ ). The contact between Units II and III appears as a slightly irregular erosion surface and is clearly visible in the FMS images at 133 mbsf. Highly resistive interbeds within Unit III, similar to those seen in FMS images from Unit IV at Site 966, are interpreted as chert stringers (Fig. 17). Core recovery was poorest in zones with significant numbers of these resistive beds (e.g., Core 7R), and the presence of fragments of chert in these cores as well as in other cores supports this image interpretation. Thin beds of concentrated foraminifers in the recovered core material are interpreted as evidence for some degree of reworking of these sediments by current activity. Thin sections of these chalks show a homogeneous texture and a horizontal fabric outlined by streaks of organic material (Plate 2, fig. 1). Pyrite is commonly present in trace to small percentages.

The foraminifer and nannofossil biostratigraphies suggest an extended hiatus from the late Eocene to the Late Cretaceous between Cores 7R and 8R at 177 mbsf. Although the lithologies above and below this level are very similar (both chert-bearing foraminiferal chalks), a slight offset in both the sonic and magnetic susceptibility logs marks the location of the unconformity. The hiatus is interpreted as a submarine erosional unconformity or the artifact of a fault offset (normal), because there is no evidence for extended periods of nondeposition such as a cemented hardground.

The Cretaceous foraminiferal chalks are present down to a depth of about 420 mbsf, below which they are interbedded with calcarenites (grainstones). Echinoderms are present below $350 \mathrm{mbsf}$, and mollusks below about 398 mbsf. Depth constraints are lacking owing to extremely poor core recovery, which averaged around $1 \%$ for the lowest $250 \mathrm{~m}$ of the hole. Pieces of very organic-rich, often laminated sediment were recovered in cores between about 370 and 400 mbsf (Plate 2, fig. 2). The increase in benthic fauna coincides with an over- 


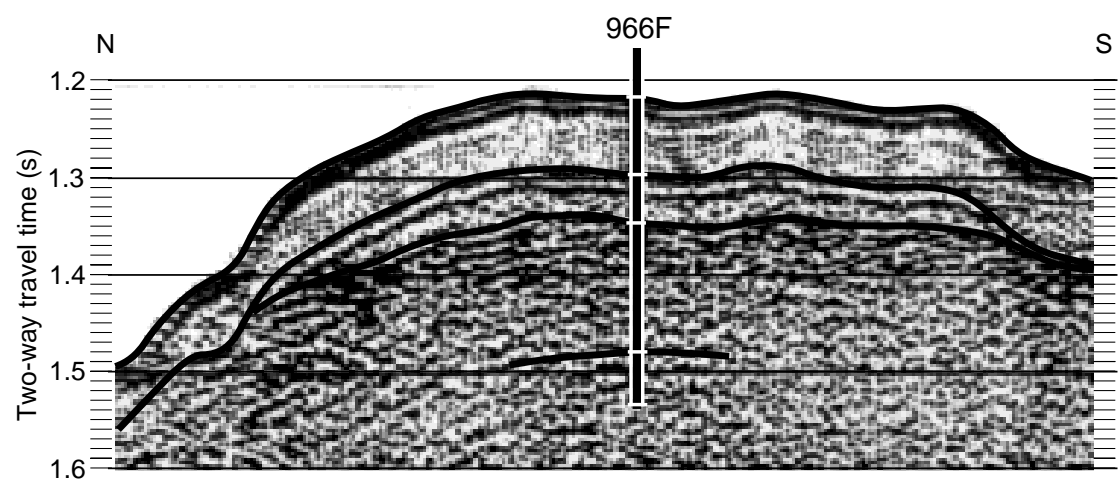

Figure 7. A section of Tredmar line 120 across Site 966 showing the superposition of the various lithostratigraphic units. Note that the Messinian matrix-supported breccia forms a lens-shaped deposit thickest on the crest of the northern summit region.

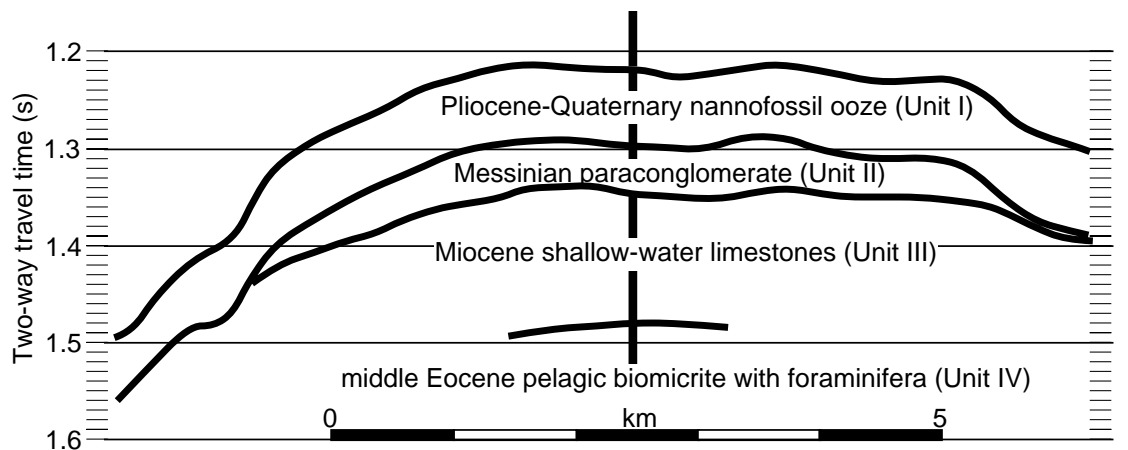

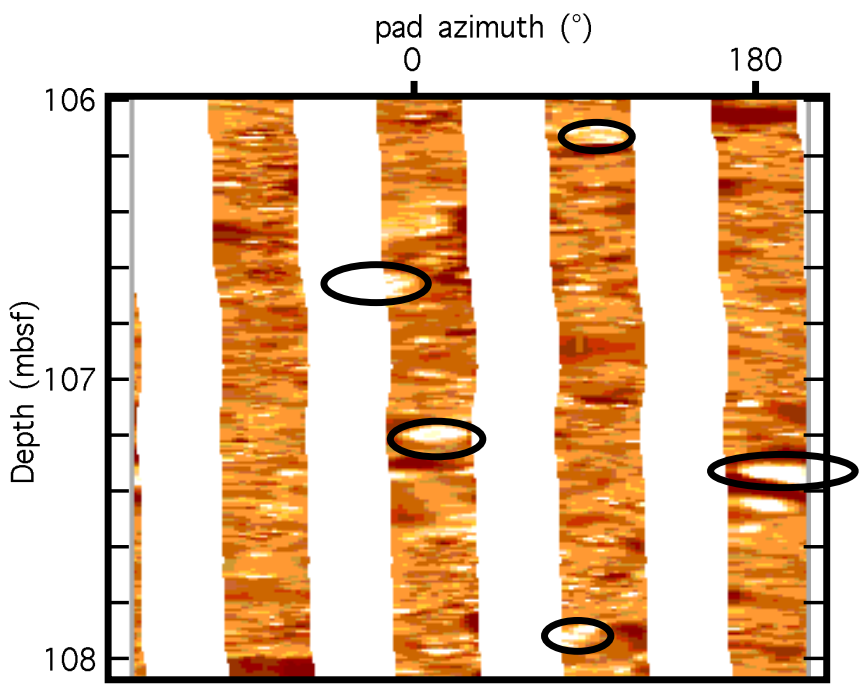

Figure 8. FMS image of the Messinian paraconglomerate, lithostratigraphic Unit II of Site 966. Ovals show locations of large clasts or concretions.

all increase in gamma-ray and resistivity log values. FMS images show interbedding of more and less resistive layers on a scale of several meters, which is consistent with an alternation between grainstones and wackestones that is evident despite the limited core recovery.

Unit III passes into lithostratigraphic Unit IV at $427 \mathrm{mbsf}$ at a level where the formation becomes more indurated. Algae occurs below $\sim 445 \mathrm{~m}$ in Hole 967E, indicating either deposition within the photic zone or redeposition of material deposited within the photic zone. The algae and coral-bearing sediments recovered in the cores are coarse grainstones and mudstones. There is some indication of algal binding, which would suggest that these sediments have not been extensively reworked. Although FMS image quality is diminished in this interval because of poor hole conditions, there is evidence of hor- izontal bedding on a submeter scale. Standard wireline logs show moderate, relatively stable resistivity and gamma-ray values in the upper part of this bedded unit, with both increasing in the bottom 20 $\mathrm{m}$ to a depth of about $525 \mathrm{mbsf}$.

Lithologies recovered from the bottom of Hole 967E are predominantly calcarenite and chert with minor pelagic microfossils. Cores $46 \mathrm{R}$ to $51 \mathrm{R}$ (542.5 to $600.3 \mathrm{mbsf}$ ) contain evidence of shearing and brecciation, which was interpreted shipboard as evidence that the hole had punched through a fault zone (Plate 2, fig. 3). Thin sections show stylolites and other pressure solution features (e.g., along grain boundaries). Breccia textures are also clearly evident in the FMS images (Fig. 18). Both mudstones and grainstones were recovered from within this deformed interval.

Although core recovery was very low in the deeper parts of this hole (including 5 cores with no recovery), the stratigraphy seems to suggest an overall fining-upward sequence through Unit IV and Unit III. Postcruise biostratigraphy has shown that shallow-water carbonate deposition ended in the late Aptian and that pelagic sedimentation is likely to have begun in the Cenomanian (Premoli Silva et al., Chap. 30 , this volume).

\section{DISCUSSION}

\section{Miocene Paleoenvironments}

The late Miocene was a period of pervasive reef development throughout the Mediterranean Basin. Tortonian to early Messinian reefs are found on the Levant and Egyptian Margins (Table 6). The appearance of reefal limestones capping deltaic clays and silty marls in the Nile Delta area suggests a anomalous burst of productivity in an area previously inhospitable to carbonate build-up. During the latest Miocene and just prior to the desiccation phase, productivity was greatly enhanced throughout the Mediterranean basin owing to the siphoning effect of nutrient-rich Atlantic water through the Rifian corridor (Benson et al., 1991). Deeper settings experienced an onset of diatom sedimentation at this time (Tripoli Formation) (McKenzie et al., 1979; Rouchy and Saint Martin, 1992), which corresponds chronostratigraphically with the global carbon shift seen through the 


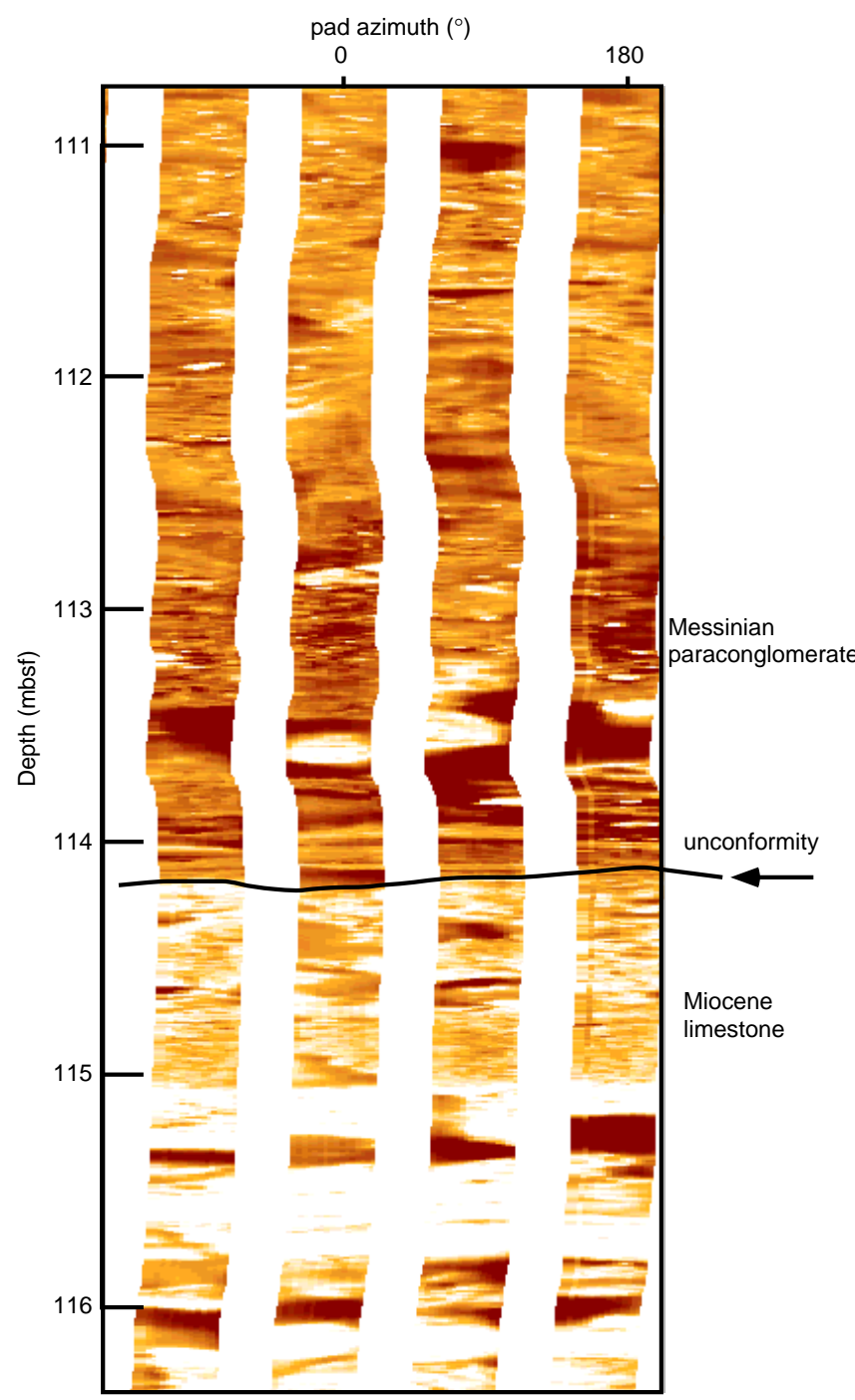

Figure 9. FMS image of the contact between the Messinian matrix-supported breccia and the underlying Miocene shallow-water limestones (Site 966).

world's oceans (Benson et al., 1995; Benson and Rakic-El Bied, 1996; Hodell and Kennett, 1985; Loutit and Keigwin, 1982). The laminated diatomites reflect the onset of strong, cyclic upwelling, which may have provided nutrients for the coral reefs that fringed the shorelines of Spain, Morocco, Algeria, Sicily, Italy, Crete, and Cyprus. The shallow-water carbonate sections recovered and logged on the summit and flank of Eratosthenes Seamount document a burst of productivity that occurred during the tectonic closure stage of the Gibraltar seaway (Esteban and Giner, 1980; Esteban, 1980; Pomar, 1991).

A progressive decrease in coral diversity has been observed throughout the Miocene in the Western Mediterranean, culminating in Messinian reefs dominated only by the hermatypic coral genus Porites sp. (Esteban et al., 1978), a salinity-tolerant taxon. However, diverse reef assemblages, including several coral species, large echinoids, bivalves, Heterostegina, bryozoans, and red algae, persisted for a longer period of time in the Eastern Mediterranean than the Western Mediterranean, probably because proximity to the cold waters entering the western basin through the Atlantic portal inhibited the growth of diverse reef fauna (Esteban, 1980). Shallow-water carbonates with a diverse faunal assemblage, including many of the above taxa, were recovered at both Sites 965 and 966. Without the

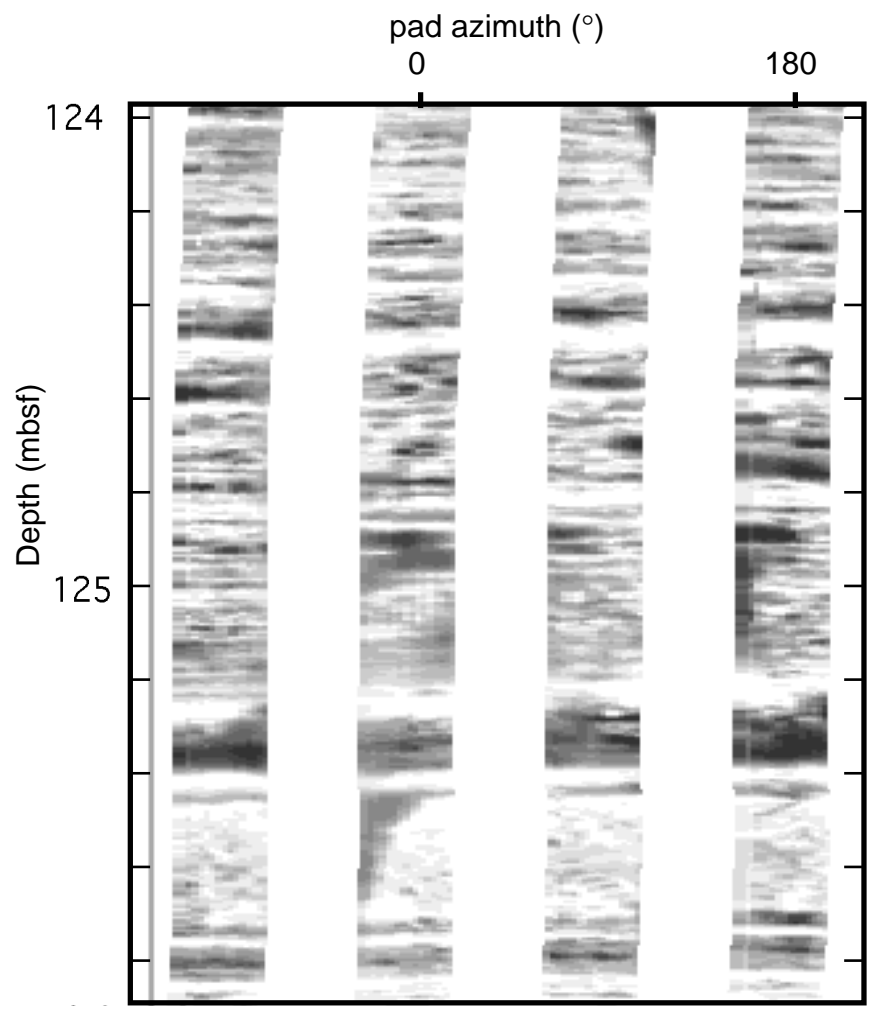

Figure 10. FMS image of thin-bedded Miocene grainstone (Site 966).

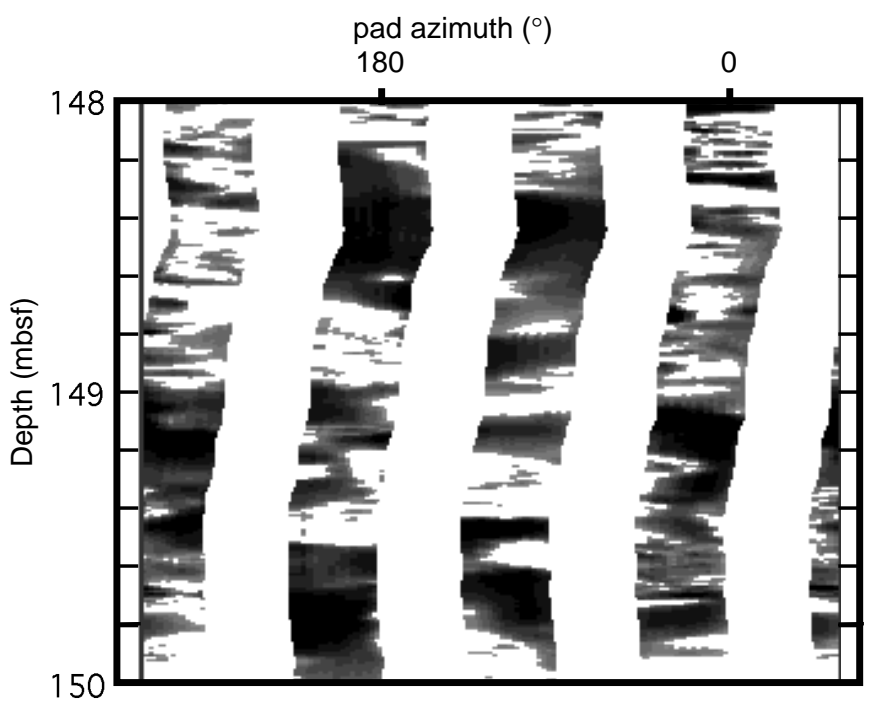

Figure 11. FMS image of chaotic patchy floatstone of Unit IIIA (Site 966).

presence of age-diagnostic fauna or reliable absolute dates, the possibility that the Eratosthenes reefs persist into the early (pre-evaporitic) part of the Messinian cannot be discounted. In any case, the presence of the reefs points to a neritic environment existing on the summit and flanks of Eratosthenes in the late Miocene, which implies that the seamount was in a substantially shallower depth before the Messinian salinity crisis.

All three sites drilled on Eratosthenes Seamount record some expression of the late Miocene (Messinian) isolation and desiccation of the Mediterranean (Fig. 19) which followed the reef-building phase. Site 967 at the base of the northern flank penetrated a thin layer of evaporites where they have just onlapped the side of the edifice. The 


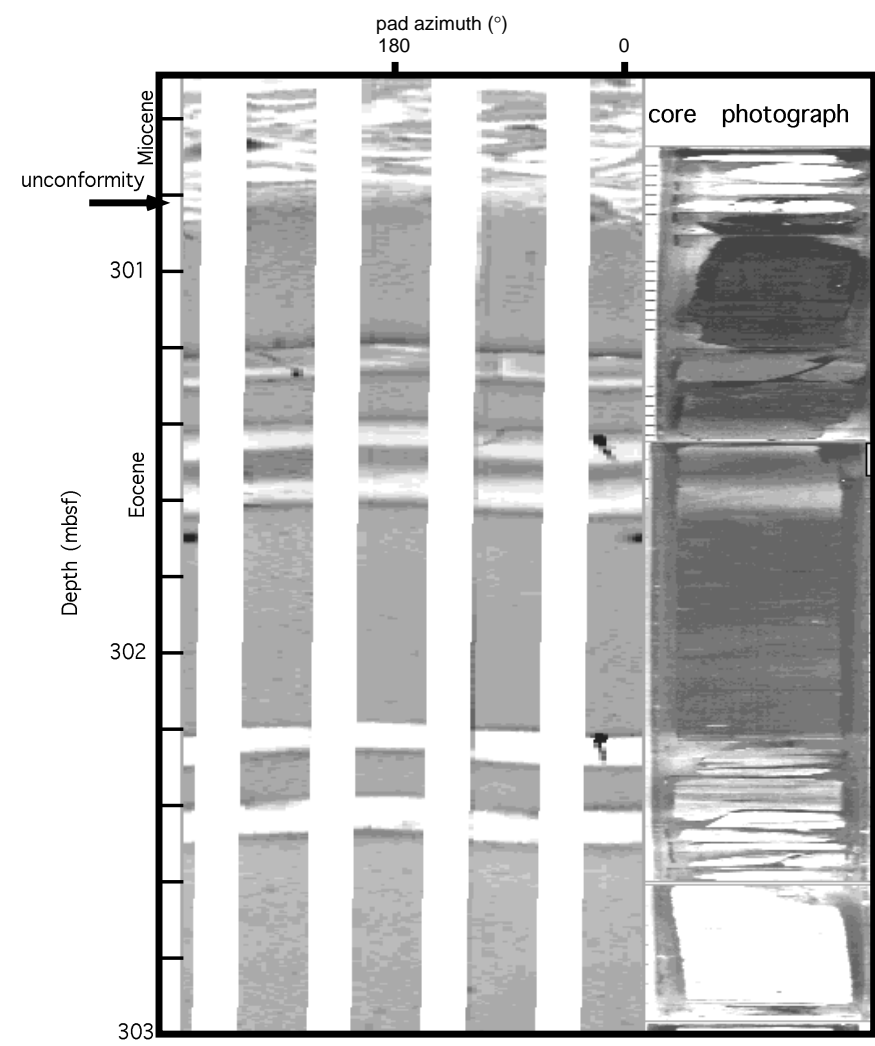

Figure 12. Formation MicroScanner image of the unconformable contact between the Miocene (lithostratigraphic Unit IIIB) and the Eocene (Unit IV). To the right is a photograph of the recovered core interval scales to the same dimensions as the FMS image. Note the white limestones of Unit III overlying the black, bituminous limestones of Unit IV. transformation of the briny playa lake in which the evaporite was deposited into a brackish sea during Lago Mare time explains the presence of in situ ostracodes in the overlying layers. This transgression submerged the evaporite and initiated the accumulation of the Lago Mare sediments recovered in Cores 967E-13H to 967E-15X.

Sites 965 and 966, sitting at shallower depths on the seamount, experienced emergence during the desiccation phase of the Messinian. The irregular unconformable surface between the Miocene limestones and the overlying unit is thus a karstified subaerial erosional surface. The high degree of solution porosity and lack of marine cementation fabrics seen in the shallow-water limestones of the summit and flank areas is the effect of meteoric diagenesis and dissolution during this subaerial phase.

Site 967 at the base of the northern flank penetrated a thin layer of evaporites where they barely onlap the side of the edifice. The transformation of the briny playa lake in which the evaporite was deposited into a lake during Lago Mare time explains the presence of in situ brackish water ostracodes above the evaporite layer seen in the logs. The inundation of the salinas and sabkhas by a brackish lake terminated the evaporitic stage of the Messinian and initiated the accumulation of the Lago Mare sediments recovered in Cores 967E-13H to 967E-15X.

\section{Significance of the Matrix-Supported Breccia}

Above the Messinian erosional surface and below the sapropelbearing nannofossil oozes at the summit and flank sites, there is a lens of matrix-supported carbonate breccia with thickness varying from a few meters (at Site 965) to greater than $50 \mathrm{~m}$ (at Site 966). The 4 closely space holes that penetrated this unit at Site 966 reveal that the thickness varies by more than $20 \mathrm{~m}$ at that site alone (Shipboard Scientific Party, 1996b). In seismic profiles this unit displays a sharp, coherent top reflector, indicating a fairly smooth, even surface and a substantial acoustic impedance contrast with the overlying nannofossil oozes. The seismically defined base of the unit is a highly reverberant, jumbled reflector (Fig. 4). Seismic profiles also show that this unit is thickest on isolated topographic highs (inferred uplifted fault blocks), and thins toward the edges of the inferred fault blocks. On topographic steps, the unit thins toward the seaward edge. The ma-

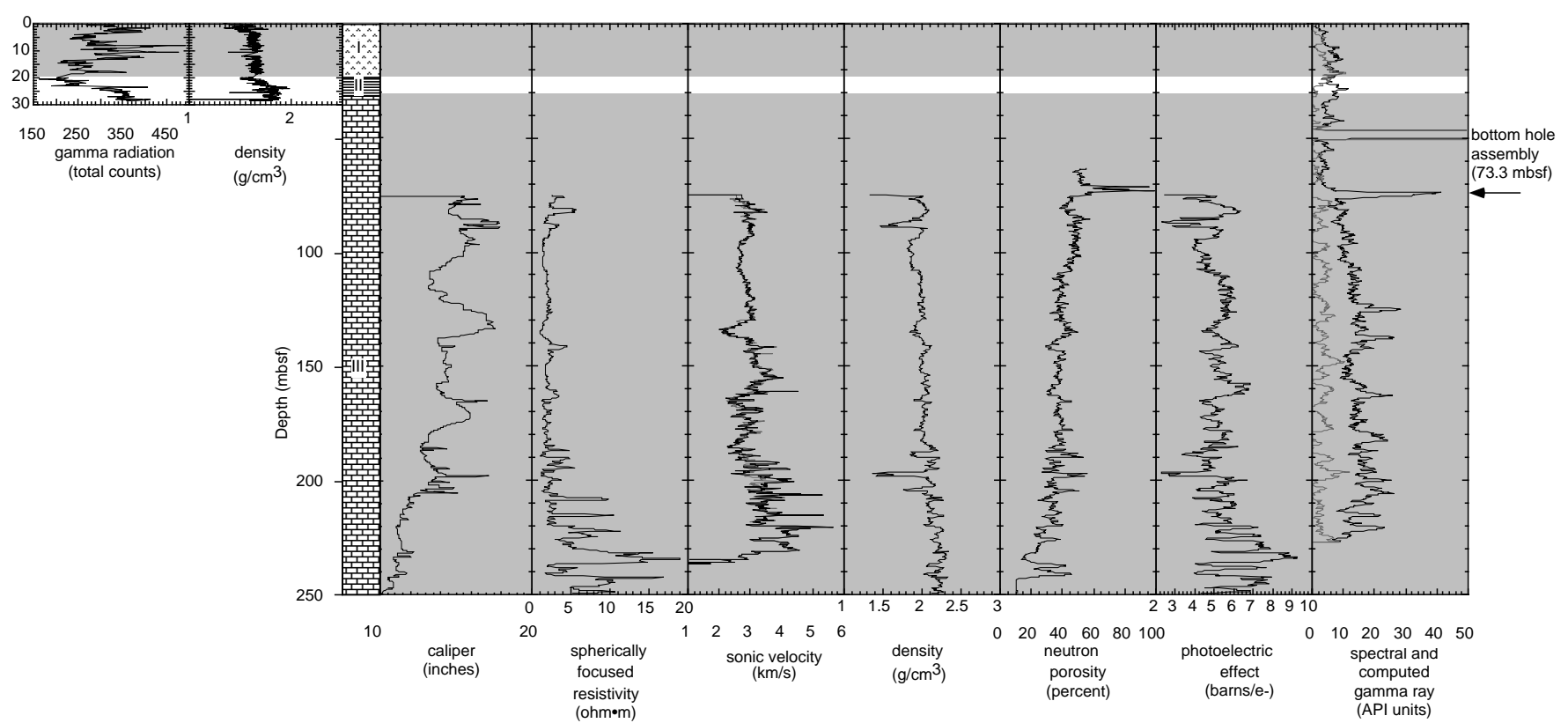

Figure 13. Summary of logs from Hole 965A. Column on left shows the three major lithostratigraphic units described in the text. 


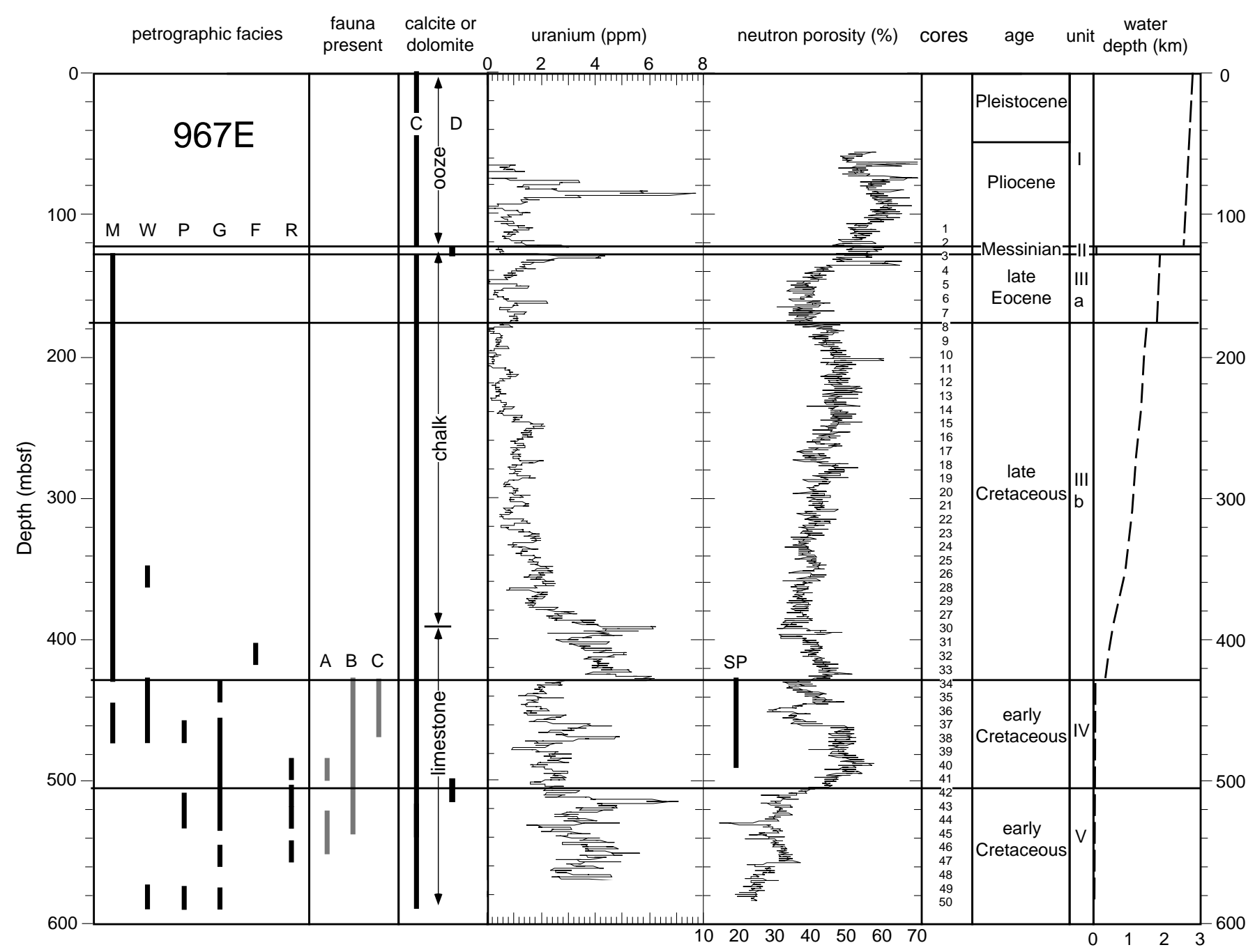

Figure 14. The interpreted petrographic facies $(\mathrm{M}=$ mudstone, $\mathrm{W}=$ wackestone, $\mathrm{P}=$ packstone, $\mathrm{G}=$ grainstone, $\mathrm{F}=$ floatstone, $\mathrm{R}=$ rudstone $)$, bioclasts $(\mathrm{A}=$ algae, $\mathrm{B}=$ bryozoans, $\mathrm{C}=$ coral), porosity $(\mathrm{SP}=$ solution porosity present), and logs from Site 967 from the base of the northern flank of Eratosthenes Seamount. Water depth is inferred from depositional facies.

trix-supported breccia is represented in the logs as an interval of low resistivity relative to the underlying indurated limestones at both Site 965 and 966.

Shipboard biostratigraphers have noted a discrepancy in the biostratigraphic zone boundaries between the 4 holes (A, C, D, and F) which penetrated the matrix supported breccia at Site 966 . This unit (lithostratigraphic Unit II) has been assigned to MNN12 and MPL2 (earliest Pliocene). However, the observed fauna raise questions.

Nannofossil tests show strong overgrowths, a phenomenon also present in the $9 \mathrm{~m}$ of nannofossil oozes overlying the matrix-supported breccia. A general decline in abundance through the unit (e.g., Cores 966A-7H-4 through CC) was also observed. One sample from a clast within the matrix-supported breccia in Hole F, 15 m below the top of the unit, contains a nannofossil assemblage indicating early Messinian age based on the presence of $R$. reticulofenestra. No nannofossils were identified from the matrix in the upper $10 \mathrm{~m}$ of the breccia due to severe overgrowths and commonly barren nature of the recovered material. However, at a depth of $\sim 10 \mathrm{~m}$ below the top of the unit a diverse assemblage (list species) was identified. Based on the absence of $H$. sellii, this assemblage was assigned to the MNN12 zone of the earliest Pliocene (early Zanclean in the Mediterranean).
Outside the Mediterranean the same assemblage would be assigned to the NN12 zone, whose base lies well within the Messinian, and even NN11, which extends to the early Messinian. Without the presence of other age diagnostic species (e.g., D. quinqueramus) the distinction between a Pliocene and Messinian age cannot be made (Berggren et al., 1995; D. Castradori, pers. comm., 1997). If this assemblage is as old a early Messinian one might argue that it should contain other late Miocene species (e.g., D. quinqueramus, D. berggreni), though this is not strictly necessary. In short, the observed nannofossil assemblage contains no fauna that require an early Pliocene vs. early Messinian age. The presence of rare G. margaritae and Sphaeroidinellopsis sp. in Hole 966A-13X-CC is likely due to downhole contamination rather than reworking (M.B. Cita, pers. comm., 1997).

Using the first and last appearance data of nannofossils and foraminifers from Hole 966A, an age-depth diagram may be constructed that shows a rather uniform sedimentation rate through the overlying nannofossil oozes, averaging $13.3 \mathrm{~m} / \mathrm{m} . y$. (Fig. 20; Table 7). An extrapolation of the age-depth model would place the base of the Zanclean (5.32 Ma) at $\sim 70.7 \mathrm{mbsf}$, close to the depth of $69 \mathrm{mbsf}$ inferred from the seismic profile over the drill site. 


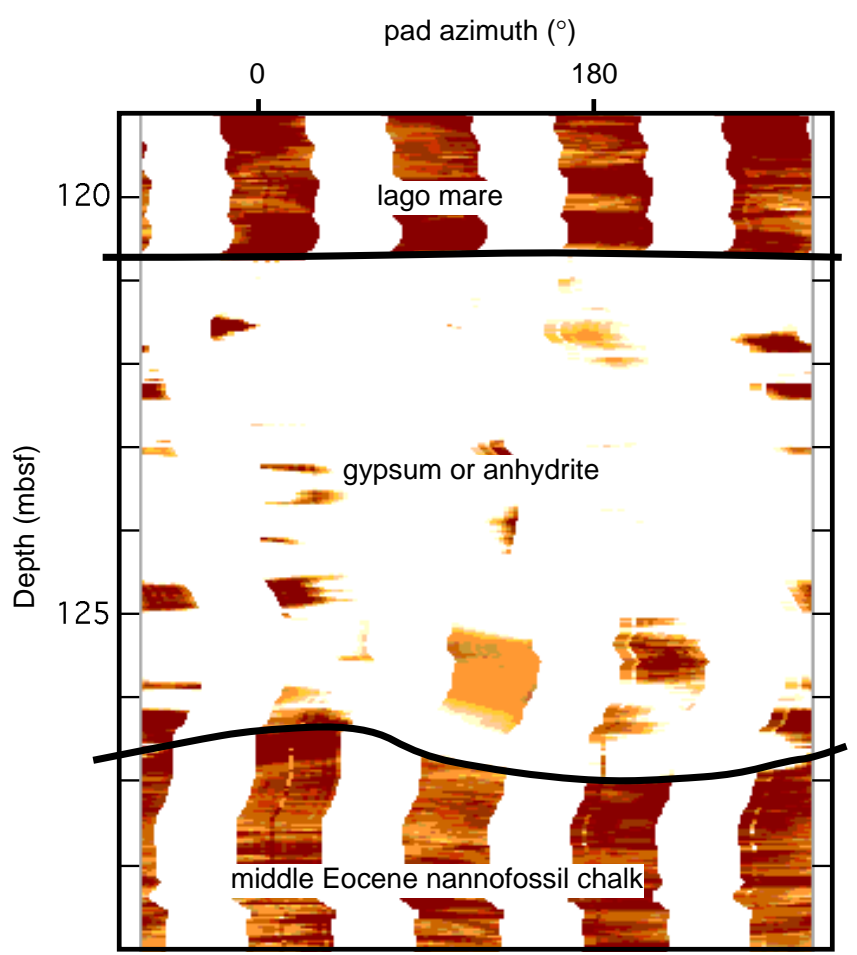

Figure 15. FMS image of the $\sim 5$-m-thick gypsum layer overlying upper Eocene foraminiferal nannofossil chalk. This erosional unconformity is quite irregular on a small spatial scale.

At Site 965 on the northern flank of the seamount where the seismic unit thickness is much less than at Site 966 and includes a paleosol layer and ostracodes, a definitive age assignment is again problematic. The deposit here contains rare A. delicatus, a species with first appears in the Mediterranean in the pre-evaporitic Messinian but ranges into the Zanclean stage of the early Pliocene. D. asymmetricus, whose first appearance datum coincides very closely with the beginning of the Zanclean, is not present, nor are any other species that evolved after the end of the Messinian. Thus a Messinian age is again consistent with the observed fauna.

Robertson et al. (1996a) (shipboard report and subsequent papers) assign an early Pliocene age to the matrix-supported breccia and attribute the unit to debris-flows that came from exposed fault scarps in the summit and flank areas of the seamount. The FMS log images show clast-rich and clast-poor zones and confirm that the matrixsupported breccia is not an artifact of drilling disturbance. Indeed, the seismic reflection profiles show that faults have influenced the distribution and thickness of this deposit, indicating that the fault scarps must have developed before or during the formation of the unit. However, as a seismic unit, the matrix-supported breccia is found in summit areas where it could not have been come from an uphill fault scarp.

An alternative explanation is that the matrix-supported breccia is a product of subaerial weathering of the exposed carbonate platform during episodes of desiccation, interspersed with periods of drowning at times of substantial marine influx from the Atlantic. Repeated submergence and emergence, in a combination of near-shore constructional events and terrestrial erosional events, could have resulted in the deposition of Unit II. Overgrowth of microfossil tests would be consistent with meteoric diagenesis, which at times was severe enough to obliterate the original tests and create barren zones. The presence of evaporite and inorganic calcite fragments within the breccia further suggest diagenesis in an evaporitic environment. An- other possibility is that Messinian exposure of the platform created a delicate karst surface which collapsed and filled low areas during the terminal Messinian flooding event which permanently drowned the seamount. This essentially instantaneous transgression may have washed loose fragments of the carbonate platform limestones into a sedimentary deposit.

The substantial thickness and volume of the matrix-supported breccia, however, presents problems for creating the deposit in the brief interval of the terminal drowning. We find it significant that breccia deposits are not found intercalated within the overlying nannofossil-rich oozes, though the fault-generated relief is still apparent at the present time. Furthermore, high-resolution swath bathymetry shows no evidence of reentrants nor lobate fan structures along the fault scarps as might be expected if the substantial volume of the matrix-supported breccia were in fact generated by erosion of exposed fault faces.

Studies of the sedimentary sections in the Nile Delta area describe a unit, the Abu Madi sands, occurring between the Messinian evaporite deposits (Rosetta Formation) and the overlying Pliocene marine deposits (Kafr El Sheik Formation; Rizzini et al., 1978; Barber, 1981). Similar units have also been described from other locations in the Eastern Mediterranean (Table 6). Rizzini et al. (1978) describe this unit as comprising thick sandy and conglomeratic layers which commonly display slump structures. These deposits are poorly sorted, and commonly have a massive microconglomerate nature, with sedimentary structures typical of high-energy deposits associated with fauna typical of quiet restricted environments (Rizzini et al., 1978). This unit passes upward into the Kafr El Sheik deep marine clays; in other words, the unit is a fining-upward sequence capped by marine clays (Rizzini et al., 1978). Foraminifers are found in the clayey interlayers in the upper part of the unit, belonging to the Sphaeroidinellopsis sp. Zone, which is the lowermost biozone of the Pliocene in the Mediterranean. Slumping in this unit is attributed to instabilities in the unconsolidated sands caused by the abrupt largescale transgression at the end of the Messinian. Although the contemporaneous deposits on the Eratosthenes Seamount are carbonates rather than siliciclastics, it seems reasonable that similar slumping events could generate a thick deposit of conglomeratic material like the matrix-supported breccia in unconsolidated material generated by weathering processes during the emergent phase of the seamount. No tectonic instability is required for the generation of these units.

\section{Seamount Shallowing (Eocene-Miocene)}

The shallowing of the seamount summit between the middle Eocene and the late Miocene lacks a satisfactory explanation related to a link between the thermal evolution of the lithosphere and global eustacy. It therefore seems likely that tectonics have played a role in controlling the shallowing of depositional environments seen in the Eratosthenes cores for this time interval. The presence of mixed middle Eocene, Oligocene, and lower Miocene planktonic foraminiferal assemblages in the lower part of Hole 967A (Core 15X) records the existence of pelagic sedimentation in the area during these times. The presence of the benthic foraminifer group Orbitoidae in the lower part of Unit III (Subunit IIIA) indicates that there had been substantial shallowing of the summit area by the lower Miocene. Several possible explanations for the uplift to shallow depths have been explored.

Megascale uplift of the African continent took place gradually throughout the Cenozoic and resulted in a shallowing-upward sequence on the African margin in the Nile delta area as increased sediment load caused outbuilding of the delta (Barber, 1981). Since Eratosthenes sits relatively close to the African continent, it is possible that it felt the effects of this broad uplift. Another possible mechanism for the uplift is the southward migration of the peripheral bulge of the descending African plate seaward of the subduction zone, 


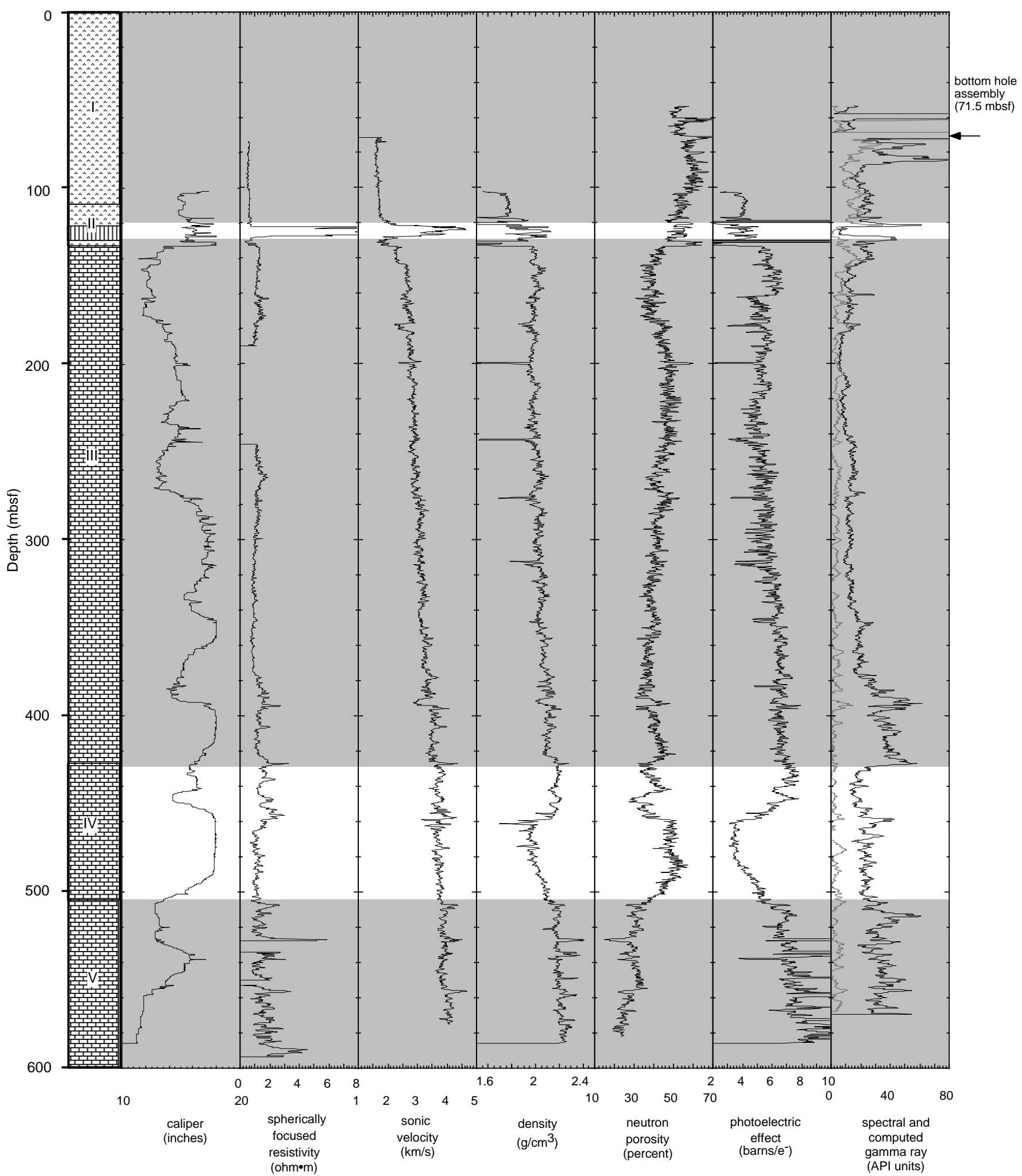

Figure 16. Summary of logs from Hole 967E. Column on left shows the five major lithostratigraphic units described in the text. 


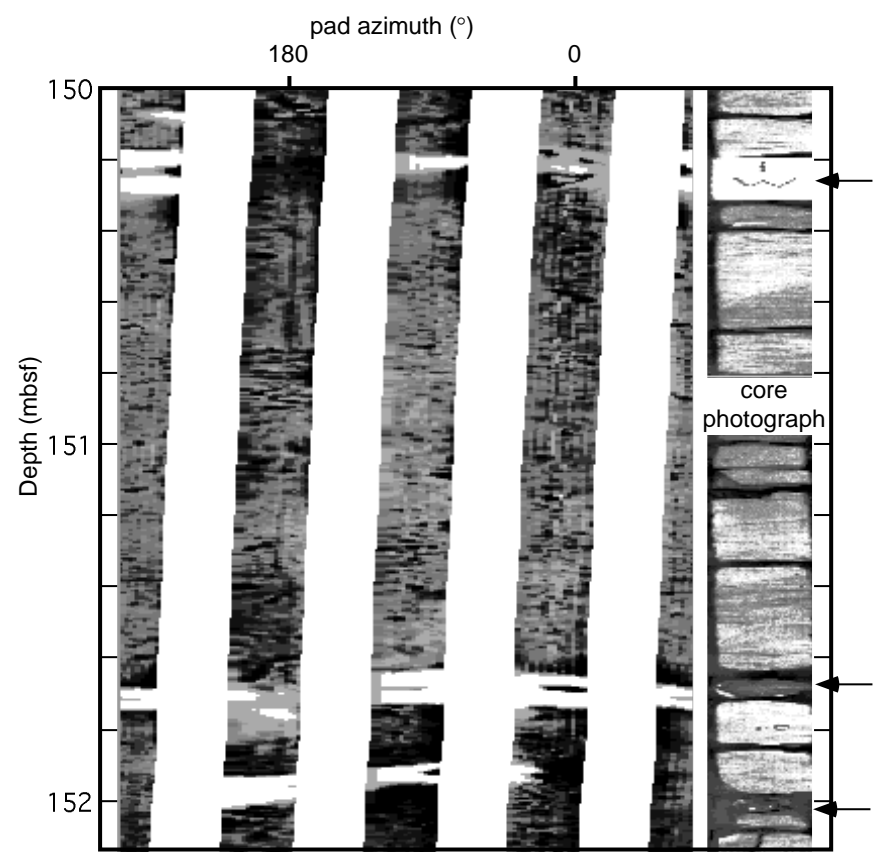

Figure 17. Formation MicroScanner image of highly bioturbated chalk from lithostratigraphic Unit III at Site 967, compared with core photograph. Bottom arrows point to cherts recovered in the core that correlate with chert stringers in the FMS image. Top arrow points to interstitial water sample.

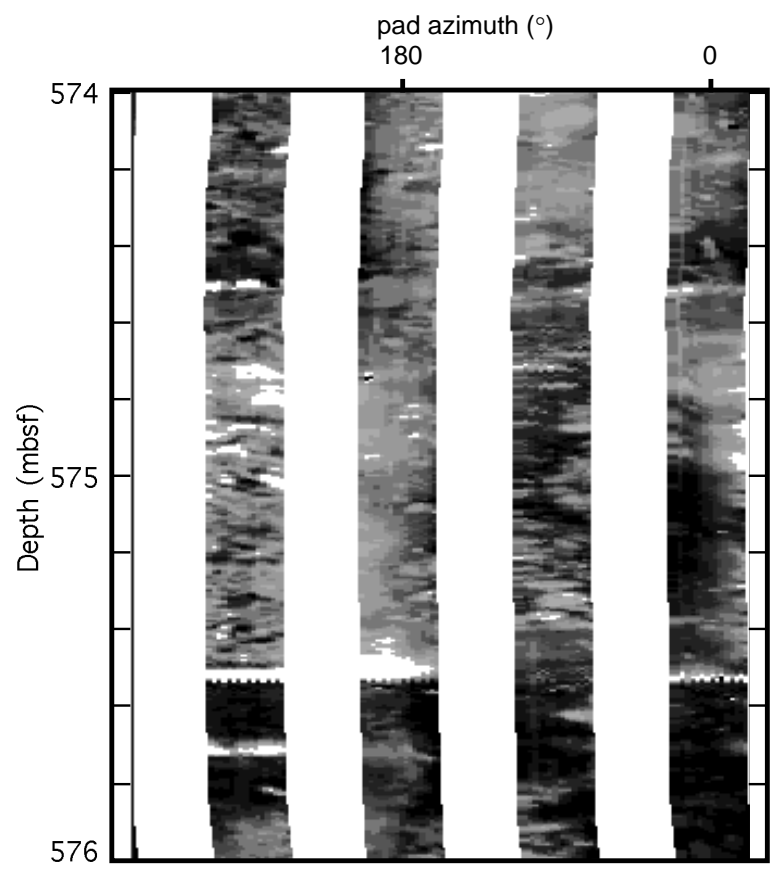

Figure 18. Formation MicroScanner image of early Cretaceous brecciated shallow-water limestone of lithostratigraphic Unit V (Site 967).

which would accompany further closure of the Mediterranean. The apparent timing of the uplift, constrained by the appearance of bioclastic grainstones in the summit area (Subunit IIIA), is consistent and Woodcock, 1980; Kempler and Ben-Avraham, 1987). The development of a large peripheral bulge, however, is not likely to occur early in the evolution of a subduction zone because of the small radius of curvature of the descending plate. In addition, no more than a with the onset of northward subduction beneath Cyprus (Robertson

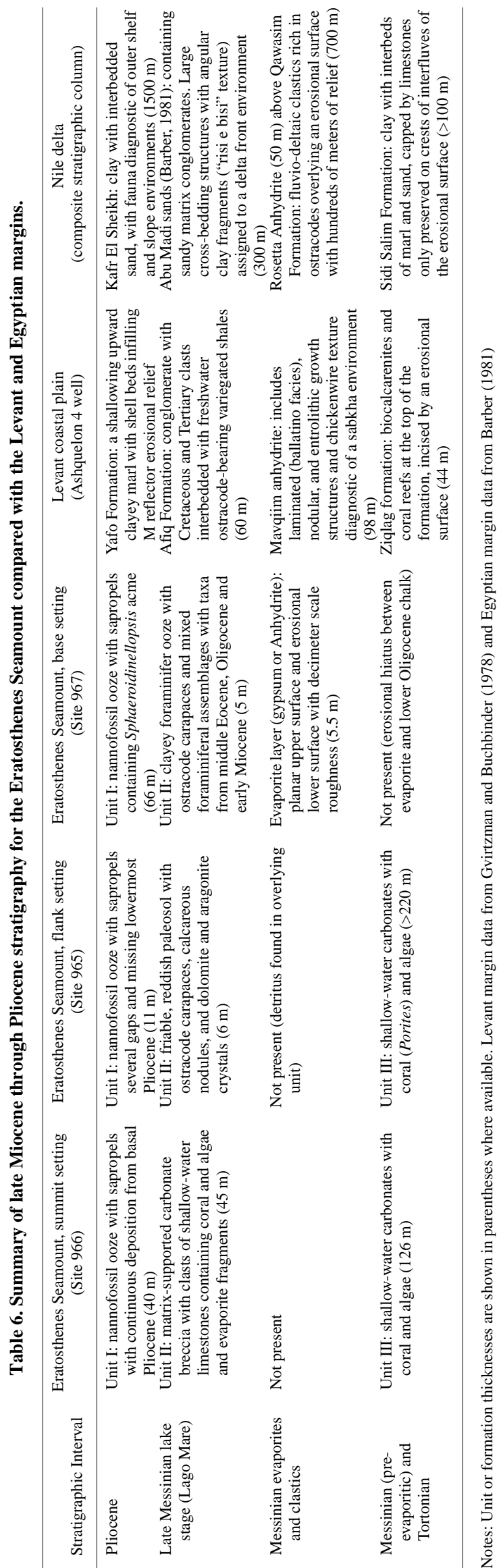




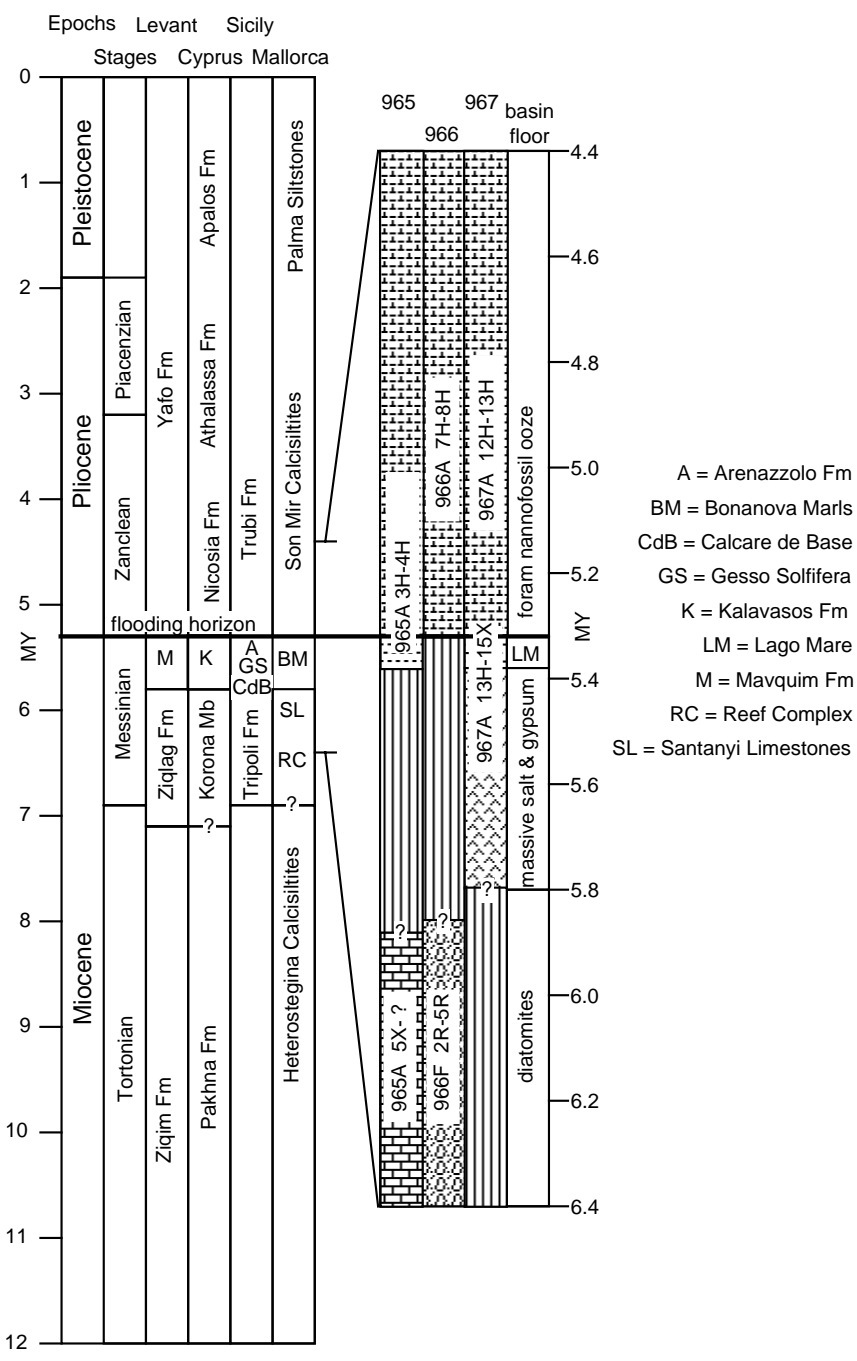

Figure 19. Composite stratigraphy for period around the Miocene/Pliocene boundary showing sediments recovered and/or logged in the three sites drilled on the Eratosthenes Seamount (adapted from Pomar, 1991; Eaton and Robertson, 1993; Gvirtzman and Buchbinder, 1978; Ogniben, 1957; McKenzie et al., 1979).

few hundred meters of uplift can be accomplished by this mechanism (Abbott and Fisk, 1986).

An alternative to large-scale uplift is deep seeding of reefs with subsequent rapid aggradation by carbonate buildup on the Eratosthenes plateau area. Esteban (1980) noted that Mediterranean reefs can seed in $200 \mathrm{~m}$ water depth. In this scenario, upward growth of the reef would outstrip the rate of thermal and loading subsidence and result in a shallowing succession of facies. However, the thickness of the entire Miocene section represented on the summit area is only 186 $\mathrm{m}$. Upward accretion would be accompanied by loading subsidence of about half the thickness of the load, and so upward accretion is likely to account for no more than $100 \mathrm{~m}$ of shallowing. In addition, reflection profiles show that accumulation of an even thicker Oligocene to Miocene section in the surrounding basin than on the summit. Loading of the circum-seamount should have produced as much loading subsidence as summit accretion.

\section{Eocene-Late Cretaceous Paleoenvironments}

Logs and recovered cores from Sites 966 and 967 record a long period of pelagic sedimentation, lasting at least until the middle Eocene on the summit, and at least until the early Oligocene at the

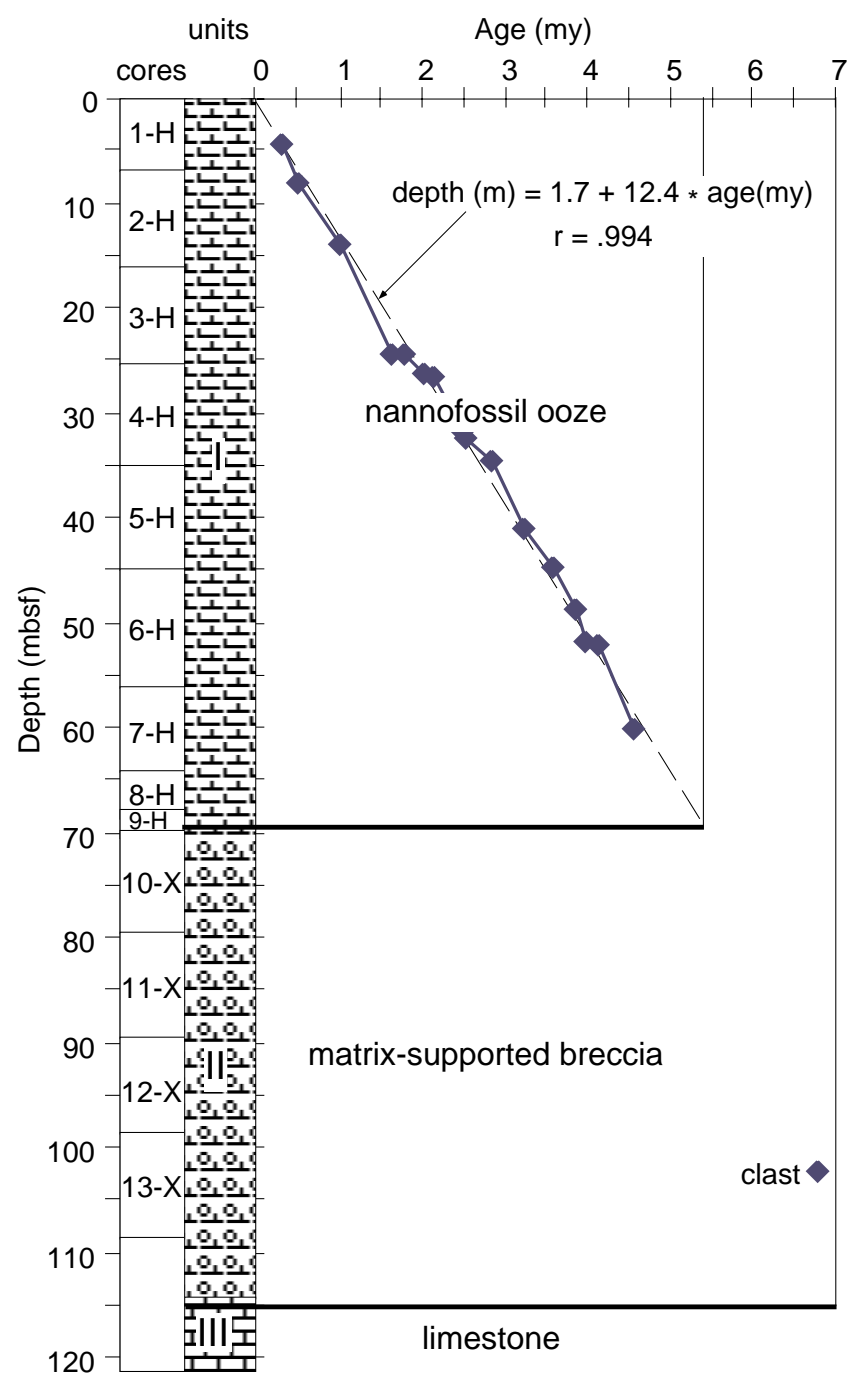

Figure 20. A plot of age vs. depth for the 16 biostratigraphic data in lithostratigraphic Unit I of Hole 966A (summit of Eratosthenes Seamount) listed in Table 7. The depicted age model shows a relatively constant rate of sediment accumulation without significant breaks. A linear regression of the data extrapolates to a depth of $70 \mathrm{~m}$ for the known age of the basal Pliocene reflooding of the Mediterranean at $5.32 \mathrm{my}$. This age-model-derived depth is within $1 \mathrm{~m}$ of the top of the 45 -m-thick matrix-supported breccia of lithostratigraphic Unit II. The latter formation consists of material formed during the terminal Miocene and which may have been reworked to some degree during the rapid transgression at the Miocene/Pliocene boundary.

base of the seamount. The presence of carbonate sediments through the Cenozoic and Mesozoic intervals represented by drilled strata on Eratosthenes indicates that at no time did any of the seafloor here subside below the calcite compensation depth (CCD), even during the Turonian and Campanian stages of the Late Cretaceous when (abyssal) red clays and radiolarites were accumulating on a nearby spreading center now fossilized in the Troodos Massif on Cyprus (Gass, 1968). Even the deepest site drilled must have been situated well above the general level of the floor of the Eastern Mediterranean, since non-carbonate shales of Aptian age are present in the Eastern Mediterranean (i.e., extruded onto the modern seafloor by mud diapirs; Cita et al., 1981; Ryan et al., 1982). If one assumes that the Troodos spreading center lay at depths typical of active spreading centers, then the Eratosthenes flank and crest could have been above the maximum base level from at least 120 m.y. onward to the present era. 
Table 7. First and last appearance data for Pliocene to Holocene planktonic foraminifers from Hole 966A.

\begin{tabular}{|c|c|c|}
\hline Biostratigraphic datum & $\begin{array}{l}\text { Age } \\
\text { (Ma) }\end{array}$ & $\begin{array}{l}\text { Depth } \\
\text { (mbsf) }\end{array}$ \\
\hline E. huxleyi (FO) & 0.26 & 4.40 \\
\hline P. lacunosa (LO) & 0.46 & 8.00 \\
\hline Gephyrocapsa sp. 3 (FO) & 0.99 & 13.85 \\
\hline C. macintyrei (LO) & 1.62 & 24.42 \\
\hline G. oceanica (FO) & 1.75 & 24.42 \\
\hline D. brouweri (LO) & 1.99 & 26.10 \\
\hline G. inflata (FO) & 2.13 & 26.60 \\
\hline G. bononiensis (LO) & 2.45 & 31.61 \\
\hline D. pentaradiatus $(\mathrm{LO})$ & 2.51 & 32.40 \\
\hline D. tamalis (LCO) & 2.82 & 34.51 \\
\hline Sphaeroidinellopsis (LO) & 3.22 & 40.92 \\
\hline G. puncticulata $(\mathrm{LO})$ & 3.57 & 44.74 \\
\hline R. pseudoumbilicus (LO) & 3.85 & 48.72 \\
\hline G. margaritae (LCO) & 3.94 & 51.56 \\
\hline D. asymmetricus (FCO) & 4.11 & 51.98 \\
\hline G. puncticulata (FO) & 4.52 & 60.12 \\
\hline
\end{tabular}

Notes: $\mathrm{FO}=$ first occurrence; $\mathrm{LO}=$ last occurrence FCO = first common occurrence; LCO = last common occurrence. Data from Emeis, Robertson, Richter, et al. (1996).

\section{Early Cretaceous Paleoenvironments}

Early Cretaceous environments, represented by lithostratigraphic Unit IV of Site 967, are clearly indicative of a carbonate platform setting. Dolomitized limestones of a comparable age and facies were sampled from the inner wall of the Hellenic Trench at Site 127 of Leg 13 of the Deep Sea Drilling Project (DSDP; Maync, 1973). Like the brecciated limestones recovered in the bottom of Hole 967E, those from the Hellenic Trench are also extensively recrystallized and exhibit stylolitic structures.

\section{Subsidence and Depth Reconstructions}

It is evident from the onlap geometry of deeply buried strata at the base of the Eratosthenes Seamount (Fig. 3) and from the magnetic and gravity anomalies in the southeast corner of the Eastern Mediterranean that this topographic feature must have been in existence since the early Jurassic breakup of the Levant and North African continental margins (Biju-Duval et al., 1974; Dewey et al., 1973; Garfunkel and Derin, 1984; Makris and Wang, 1994; Makris et al., 1994; Robertson and Shipboard Scientific Party, 1996a; Tibor et al., 1992). It is therefore expected that the sedimentation and erosional patterns at Sites 966,965 , and 967 are at least partly controlled by their relative depth differences, as this edifice foundered and subsided after the Triassic rifting event as a consequence of the cooling and contraction of its lithospheric foundation (Watts and Ryan, 1976).

Some investigators have interpreted the sudden change of facies from late Miocene indurated shallow water platform limestones to a lower Pliocene pelagic bathyal sapropel-bearing ooze as indication of a geologically abrupt foundering of Eratosthenes Seamount as it entered the subduction zone beneath Cyprus (Robertson et al., 1996a; Whiting, 1995). Subsidence in these models is achieved by extensive normal faulting and tilting of the seamount. Normal faulting is evident in seismic profiles. Restoration of the summit and flank sites to their prefaulted depths (Fig. 21; Table 8) indicates a $194 \mathrm{~m}$ difference between the top of the Miocene sections at Site 965 and 966. A $0.8^{\circ}$ untilting of the plateau would restore the sites to the same depth, accounting for the presence of very shallow-water fauna (e.g., coral and algae) at both locations. Dips at Site 966 have been calculated from FMS images (Fig. 22) and show dips in the range of $1^{\circ}$ to $5^{\circ}$ to the northeast, which is consistent with a slight northward tilting of beds with a low depositional dip as might be expected on a slightly sloping surface (Serra, 1989). A $0.8^{\circ}$ tilt is considered an extreme case; greater abundances of coral at Site 966 than Site 965 suggest that, of the two sites, Site 966 was closer to the coral reefs (Robertson and SSP, 1996a). While it is reasonable to assume that there is some degree of northward tilting in response to entry into the trench (which may account for the presence of Porites spp. corals midway down the northern flank), as well as some normal faulting caused by flexure of the descending plate (Cadet et al., 1987), it is unlikely that the entire 1 $\mathrm{km}$ of subsidence can be attributed to extensional collapse as the seamount enters the subduction zone.

The subsidence history of the nearby southern Levant margin has been quantitatively analyzed through the one-dimensional backstripping of its sedimentary cover (Tibor et al., 1992). An Airy-type backstripping of exploration wells on the outer continental shelf reveals 3 $\mathrm{km}$ of "tectonic" subsidence with a thermal time constant of about 60 $\mathrm{Ma}$, leading to the accumulation of $7.5 \mathrm{~km}$ of sediment. The "tectonic" component of the subsidence was nearly completed by 120 m.y. ago, at which time more than $85 \%$ of the total thickness of the preMessinian sedimentary sequence had been deposited. A significant departure from the expected tectonic subsidence of the Levant margin occurs at the end of the Miocene, coincident with the period of deposition of sediments eroded off the exposed shelf areas during the Messinian draw down and the accumulation of more than a kilometer of evaporites in the deep basin (Ryan, 1978). The presence of a thick accumulation of Pliocene-Quaternary Nile-derived sediments (Yafo formation) at the Levant margin may be explained by deposition in accommodation space made by the loading of the thick Messinian clastics and evaporites in the deep basin. The highest sedimentation rates on the Levant continental shelf occur in the Pliocene before slowing again in the Quaternary (Tibor et al., 1992).

The Levant margin can serve as a model for Neogene subsidence and loading processes in the far Eastern Mediterranean. This study submits that the strong apparent subsidence of the Eratosthenes Seamount in the Miocene to Pliocene epochs (as represented by an abrupt transition from bathyal oozes and sapropels in lithostratigraphic Unit I to coralgal limestones and evaporites in lithostratigraphic Unit II at all three sites) is an isostatic phenomenon. The subsidence between 5 and 6 Ma was accentuated both by loading of extensive clastics and evaporites (reaching $\leq 1.75 \mathrm{~km}$ in thickness) on an old, flexurally rigid lithosphere, and by the return of more than $2 \mathrm{~km}$ of water at the reflooding of the Mediterranean 5.32 Ma. The continued supply of Nile sediments to the basin surrounding Eratosthenes since the end of the Miocene (see isopach map of Sage and Letouzey, 1990) has added additional subsidence to the seamount and the Levant margin.

Interpretation of the earlier environments represented in the sediments recovered from the Eratosthenes drill sites is more difficult because of the lack of age-equivalence between any of the three sites in the pre-Miocene sections. However, there is an overall apparent deepening from the Early Cretaceous through the Eocene. This observation is consistent with deposition on a thermally subsiding passive margin (Figs. 23, 24). The transition from Early Cretaceous neritic facies to upper Cretaceous bathyal pelagic facies could be the result of a transgressing sea level drowning the platform.

\section{Eratosthenes Moat}

Several authors have noted the presence of a moat-like depression around the edges of the Eratosthenes Seamount (Robertson et al., 1996). Most have ascribed this feature to the presence of bounding faults that offset the seafloor, which has served to support hypotheses for the tectonic control on the evolution of the edifice. However, seismic evidence for faulting is inconclusive. Recently, high-resolution swath bathymetry of the Mediterranean Ridge has imaged a similar moat surrounding the Bannock Structure, a conical, 50-km-wide, 3$\mathrm{km}$-high edifice that is plowing into the accretionary prism on its way into the subduction zone. Von Huene et al. (1997) suggest that the moat has been generated by dissolution of a thick evaporite sequence as fluids escaping from overpressured sediments travel up the flanks 
of the seamount. We suggest that a similar process may be occurring along the margins of the Eratosthenes Seamount, creating the steepsided moat that is observed in bathymetric maps and seismic profiles. The greater relief of the moat to the south of Eratosthenes may be related to the greater load of Pliocene-Quaternary sediment of Nile origin, which results in greater pressures and thus more efficient expulsion of pore fluids.

\section{CONCLUSIONS}

The mid-Cretaceous to Miocene carbonate sequence cored and logged at three sites on the Eratosthenes Seamount indicates an interplay of tectonics, eustatic sea level variation, and related aggradational and erosional episodes. Although the high relief of this edifice above the level of significant terrigenous input makes it a useful dipstick for determining the history of the Eastern Mediterranean basin, particularly in response to rifting and subduction and incipient collisional stages, one must be careful to consider the dynamic responses of the feature to loading, unloading, and thermal subsidence and not simply consider it a passive recorder of changing environments.

It is not necessary to hypothesize extensional faulting and collapse of the Eratosthenes Seamount in Late Miocene to early Pliocene time to explain the sedimentary successions cored and logged at Sites 965,966 , and 967 . The results of analyses of sedimentary facies from both cores and downhole logs indicate that the terminal Messinian desiccation of the Mediterranean Basin had a profound impact on the Neogene depositional and subsidence history of the Eratosthenes Seamount. The submergence of the crest of this edifice from within the photic zone in the late Miocene to bathyal depths in the lowermost Pliocene can instead be explained by the inevitable isostatic loading of a thick layer of Messinian salt, gypsum, and clastics, which were deposited in a brief interval of time between 5.8 and $5.32 \mathrm{Ma}$. Because the seamount is situated on continental crust ruptured in Late Triassic to Early Jurassic time ( 200 to $180 \mathrm{Ma}$ ), the thermal component of its subsidence is minimal by the mid-Cretaceous ( 100 Ma), as shown for the adjacent margin of the Levant (Tibor et al., 1992). A flexurally rigid lithosphere can distribute loading of peripheral regions to the seamount itself. Northward tilting of the plateau may be occurring in response to incipient subduction of the leading edge of the African margin beneath the Cypriot arc in the past few million years. However, the subsidence caused by such tilting is relatively minor compared to the substantial subsidence caused by the accumulation of the exceedingly thick sediment cover through which the Eratosthenes edifice emerges.

\section{ACKNOWLEDGMENTS}

The authors would like to thank B.C. Schreiber and an anonymous reviewer for thorough reviews of the manuscript. M. Cita, M. Steckler, L. Lavier, D. Castradori, and A.H.F. Robertson contributed helpful insight and discussion. This work was funded by a grant from USSSP (to Major).

\section{REFERENCES}

Abbott, D., and Fisk, M., 1986. Tectonically controlled origin of three unusual rock suites in the Woodlark Basin. Tectonics, 5:1145-1160.

Barber, P.M., 1981. Messinian subaerial erosion of the proto-Nile Delta. Mar. Geol., 44:253-272.

Benson, R.H., Kayek, L.-A., Hodell, D.A., and Rakic-El Bied, K., 1995. Extending the climatic precession curve back into the late Miocene by signature template comparison. Paleoceanography, 10:5-20.
Benson, R.H., and Rakic-El Bied, K., 1996. The Bou Regreg Section, Morocco: proposed Global Boundary Stratotype Section and Point of the Pliocene. Notes Mem. Ser. Geol. Maroc, 383:51-150.

Benson, R.H., Rakic-El Bied, K., and Bonaduce, G., 1991. An important current reversal (influx) in the Rifian Corridor (Morocco) at the TortonianMessinian boundary: the end of Tethys Ocean. Paleoceanography, 6:164-192.

Berggren, W.A., Hilgen, F.J., Langereis, C.G., Kent, D.V., Obradovich, J.D., Raffi, I., Raymo, M.E., and Shackleton, N.J., 1995. Late Neogene chronology: new perspectives in high-resolution stratigraphy. Geol. Soc. Am. Bull., 107:1272-1287.

Biju-Duval, B., Letouzey, J., Montadert, L., Courier, P., Mugniot, J.F., and Sancho, J., 1974. Geology of the Mediterranean Basins. In Burk, C.A., and Drake, C.L. (Eds.), The Geology of Continental Margins: New York (Springer-Verlag), 695-721.

Cadet, J.P., Koboyashi, K., Lallemand, S., Jolivet, L., Aubouin, J., Boulegue, J., Dubois, J., Hotta, H., Ishii, T., Konishi, K., Niitsuma, N., and Shinamura, H., 1987. Deep scientific dives in the Japan and Kuril Trenches. Earth Planet. Sci. Lett., 83:313-328.

Cita, M.B., 1982. The Messinian salinity crisis in the Mediterranean: a review. In Berckhemer, H., and Hsü, K. (Eds.), Alpine-Mediterranean Geodynamics. Geodyn. Ser., 7:113-140.

Cita, M.B., Ryan, W.B.F., and Paggi, L., 1981. Prometheus mud-breccia: an example of shale diapirism in the Western Mediterranean Ridge. Ann. Geol. Pays Hellen., 30:543-570.

Cita, M.B., Wright, R.C., Ryan, W.B.F., and Longinelli, A., 1978. Messinian paleoenvironments. In Hsü K.J., Montadert, L., et al., Init. Repts. DSDP, 42 (Pt. 1): Washington (U.S. Govt. Printing Office), 1003-1035.

Dewey, J.F., Pitman, W.C., III, Ryan, W.B.F., and Bonin, J., 1973. Plate tectonics and the evolution of the Alpine system. Geol. Soc. Am. Bull., $84: 3137-3180$

Dunham, R.J., 1962. Classification of carbonate rocks according to depositional texture. In Ham, W.E. (Ed.), Classification of Carbonate Rocks. AAPG Mem., 108-121.

Eaton, S., and Robertson, A.H.F., 1993. The Miocene Pakhna Formation, southern Cyprus, and its relationship to the Neogene tectonic evolution of the Eastern Mediterranean. Sediment. Geol. 86:273-296.

Emeis, K.-C., Robertson, A.H.F., Richter, C., et al., 1996. Proc. ODP, Init. Repts., 160: College Station, TX (Ocean Drilling Program).

Esteban, M., 1980. Significance of upper Miocene coral reefs of the Western Mediterranean. Palaeogeogr., Palaeoclimatol., Palaeoecol., 29:169-188.

Esteban, M., Calvert, F., Dabrio, F., Baron, C., Giner, J., Pomar, L., Salas, R., and Permanyer, A., 1978. Aberrant features of the Messinian coral reefs. Acta Geol. Hisp., 13:20-22.

Esteban, M., and Giner, J., 1980. Messinian coral reefs and erosion surfaces in Cabo de Gata (Almeria, SE Spain). Acta Geol. Hisp., 15:97-104.

Garfunkel, Z., and Derin, B., 1984. Permian-early Mesozoic tectonism and continental margin formation in Israel and its implications for the history of the Eastern Mediterranean. In Dixon, J.E., and Robertson, A.H.F. (Eds.), The Geological Evolution of the Eastern Mediterranean. Geol. Soc. Spec. Publ. London, 17:187-201.

Gass, I.G., 1968. Is the Troodos Massif, Cyprus, a fragment of Mesozoic ocean floor? Nature, 220:39-42.

Gvirtzman, G., and Buchbinder, B., 1978. The Late Tertiary of the coastal plain and continental shelf of Israel and its bearing on the history of the Eastern Mediterranean. In Ross, D.A., and Neprochnov, Y.P., et al., Init. Repts. DSDP, 42 (Pt. 2): Washington (U.S. Govt. Printing Office), 11951222.

Hall, J.K., Udintsev, G.B., and Odinikov, Y.Y., 1994. The bottom relief of the Levantine Sea. In Krasheninnikov, V.A., and Hall, J.K., (Eds)., Geologic Structure of the North-Eastern Mediterranean: Jerusalem (Historical Productions-Hall Ltd.), 5-32.

Hodell, D.A., Benson, R.H., Kent, D.V., Boersma, A., and Rakic-El Bied, K., 1994. Magnetostratigraphic, biostratigraphic, and stable isotope stratigraphy of an Upper Miocene drill core from the Salé Briqueterie (northwestern Morocco): a high-resolution chronology for the Messinian stage. Paleoceanography, 9:835-855.

Hodell, D.A., and Kennett, J.P., 1985. Late Miocene carbon shift in DSDP Site 515A, western South Atlantic. Geol. Soc. Am. Bull., 16:540.

Hsü, K.J., Cita, M.B., and Ryan, W.B.F., 1973a. The origin of the Mediterranean evaporites. In Ryan, W.B.F., Hsü, K.J., et al., Init. Repts. DSDP, 13 (Pt. 2): Washington (U.S. Govt. Printing Office), 1203-1231. 
Hsü, K.J., Montadert, L., Bernoulli, D., Cita, M.B., Erickson, A., Garrison, R.E., Kidd, R.B., Meliéres, F., Müller, C., and Wright, R., 1977. History of the Mediterranean salinity crises. Nature, 267:399-403.

Hsü, K.J., Ryan, W.B.F., and Cita, M.B., 1973b. Late Miocene desiccation of the Mediterranean Sea. Nature, 242:240-244.

Kempler, D., and Ben-Avraham, Z., 1987. The tectonic evolution of the Cyprean Arc. Ann. Tecton., 1:58-71.

Krasheninnikov, V.A., Udintsev, G.B., Mouraviov, V., and Hall, J.K., 1994. Geological structure of the Eratosthenes Seamount. In Krasheninnikov, V.A., and Hall, J.K. (Eds.), Geological Structure of the Northeastern Mediterranean (Cruise 5 of the Research Vessel Akademik Nokolaj Strakhov): Jerusalem (Historical Productions-Hall Ltd.), 113-130.

Loutit, T.S., and Keigwin, L.D., Jr., 1982. Stable isotopic evidence for the latest Miocene sea level fall in the Mediterranean region. Nature, 300:163-166.

Makris, J., and Wang, J., 1994. Bouguer gravity anomalies of the Eastern Mediterranean Sea. In Krasheninnikov, V.A., and Hall, J.K. (Eds.), Geological Structure of the North-Eastern Mediterranean: Jerusalem (Historical Productions-Hall Ltd.), 87-98.

Makris, J., Wang, J., Odintsov, S.D., and Udintsev, G.B., 1994. The magnetic field of the Eastern Mediterranean Sea. In Krasheninnikov, V.A., and Hall, J.K. (Eds.), Geological Structure of the North-Eastern Mediterranean: Jerusalem (Historical Productions-Hall Ltd.), 75-85.

Maync, W., 1973. Lower Cretaceous limestones from the Hellenic Trough, Ionian Basin (Site 127). In Ryan, W.B.F., Hsü, K.J., et al., Init. Repts. DSDP, 13 (Pt. 2): Washington (U.S. Govt. Printing Office), 1112-1119.

McKenzie, J.A., Jenkyns, H.C., and Bennet, G., 1979. Stable isotope study of the cyclic diatomite-claystones from the Tripoli Formation, Sicily: a prelude to the Messinian salinity crisis. Palaeogeogr., Palaeoclimatol., Palaeoecol., 29:125-141.

Ogg, J.G., Camoin, G.F., and Arnaud Vanneau, A., 1995. Limalok Guyot: depositional history of the carbonate platform from downhole logs at Site 871 (lagoon). In Haggerty, J.A., Premoli Silva, I., Rack, F., and McNutt, M.K. (Eds.), Proc. ODP, Sci. Results, 144: College Station, TX (Ocean Drilling Program), 233-253.

Ogniben, L., 1957. Petrographia della seie solfifera-siciliana e considerzioni geoteche relative. Mem. Descrit. Carta. Geol. Ital., 33:1-275.

Pomar, L., 1991. Reef geometries, erosion surfaces and high-frequency sealevel changes, upper Miocene Reef Complex, Mallorca, Spain. Sedimentology, 38:243-269.

Rizzini, A., Vezzani, F., Cococcetta, V., and Milad, G., 1978. Stratigraphy and sedimentation of a Neogene-Quaternary section in the Nile Delta are (A.R.E.). Mar Geol, 27:327-348.

Robertson, A.H.F., and Shipboard Scientific Party, 1996a. Role of the Eratosthenes Seamount in collisional processes in the Eastern Mediterranean. In Emeis, K.-C., Robertson, A.H.F., Richter, C., et al., Proc. ODP, Init. Repts., 160: College Station, TX (Ocean Drilling Program), 513520 .

1996b. Tectonic introduction. In Emeis, K.-C., Robertson, A.H.F., Richter, C., et al., Proc. ODP, Init. Repts., 160: College Station, TX (Ocean Drilling Program), 5-20.
Robertson, A.H.F., and Woodcock, N.H., 1980. Tectonic setting of the Troodos massif in the East Mediterranean. In Malpas, J., Moores, E.M., Panayiotou, A., and Xenophontos, C. (Eds.), Ophiolites: Oceanic Crustal Analogues. Proc. Symp. "Troodos 1987," Nicosia, Cyprus (Geol. Surv. Dep., Minist. Agric. Nat. Resour.), 36-49.

Rouchy, J.-M., and Saint Martin, J.-P., 1992. Late Miocene events in the Mediterranean as recorded by carbonate-evaporite relations. Geology, 20:629-632.

Ryan, W.B.F., 1978. Messinian badlands on the southeastern margin of the Mediterranean Sea. Mar. Geol., 27:349-363.

Ryan, W.B.F., and Cita, M.B., 1978. The nature and distribution of Messinian erosional surfaces: indicators of a several-kilometer-deep Mediterranean in the Miocene. Mar. Geol., 27:193-230.

Ryan, W.B.F., Kastens, K.A., and Cita, M.B., 1982. Geological evidence concerning compressional tectonics in the Eastern Mediterranean. Tectonophysics, 86:213-242.

Sage, L., and Letouzey, J., 1990. Convergence of the African and Eurasian Plate in the Eastern Mediterranean. In Letouzey, J. (Ed.), Petroleum and Tectonics in Mobile Belts: Paris (Ed. Technip), 49-68.

Serra, O., 1989. Formation MicroScanner Image Interpretation: Houston (Schlumberger Educ. Services), SMP-7028.

Shipboard Scientific Party, 1996a. Site 965. In Emeis, K.-C., Robertson, A.H.F., Richter, C., et al., Proc. ODP, Init. Repts., 160: College Station, TX (Ocean Drilling Program), 125-153.

1996b. Site 966. In Emeis, K.-C., Robertson, A.H.F., Richter, C., et al., Proc. ODP, Init. Repts., 160: College Station, TX (Ocean Drilling Program), 155-213.

, 1996c. Site 967. In Emeis, K.-C., Robertson, A.H.F., Richter, C., et al., Proc. ODP, Init. Repts., 160: College Station, TX (Ocean Drilling Program), 215-287.

Tibor, G., Ben-Avraham, Z., Steckler, M., and Fligelman, H., 1992. Late Tertiary subsidence history of the southern Levant margin, Eastern Mediterranean Sea, and its implications to the understanding of the Messinian event. J. Geophys. Res., 97:17593-17614.

von Huene, R., 1997. Mediterranean Ridge structure: Results from IMERSE. Eos, 78:155.

Watts, A.B., and Ryan, W.B.F., 1976. Flexure of the lithosphere and continental margin basins. Tectonophysics, 36:25-44.

Whiting, B.M., 1995. Results from Leg 160: subsidence history and tectonics of Eratosthenes "Seamount," Eastern Mediterranean. Eos, 76:625.

Date of initial receipt: 7 January 1997

Date of acceptance: 1 August 1997

Ms 160SR-033 

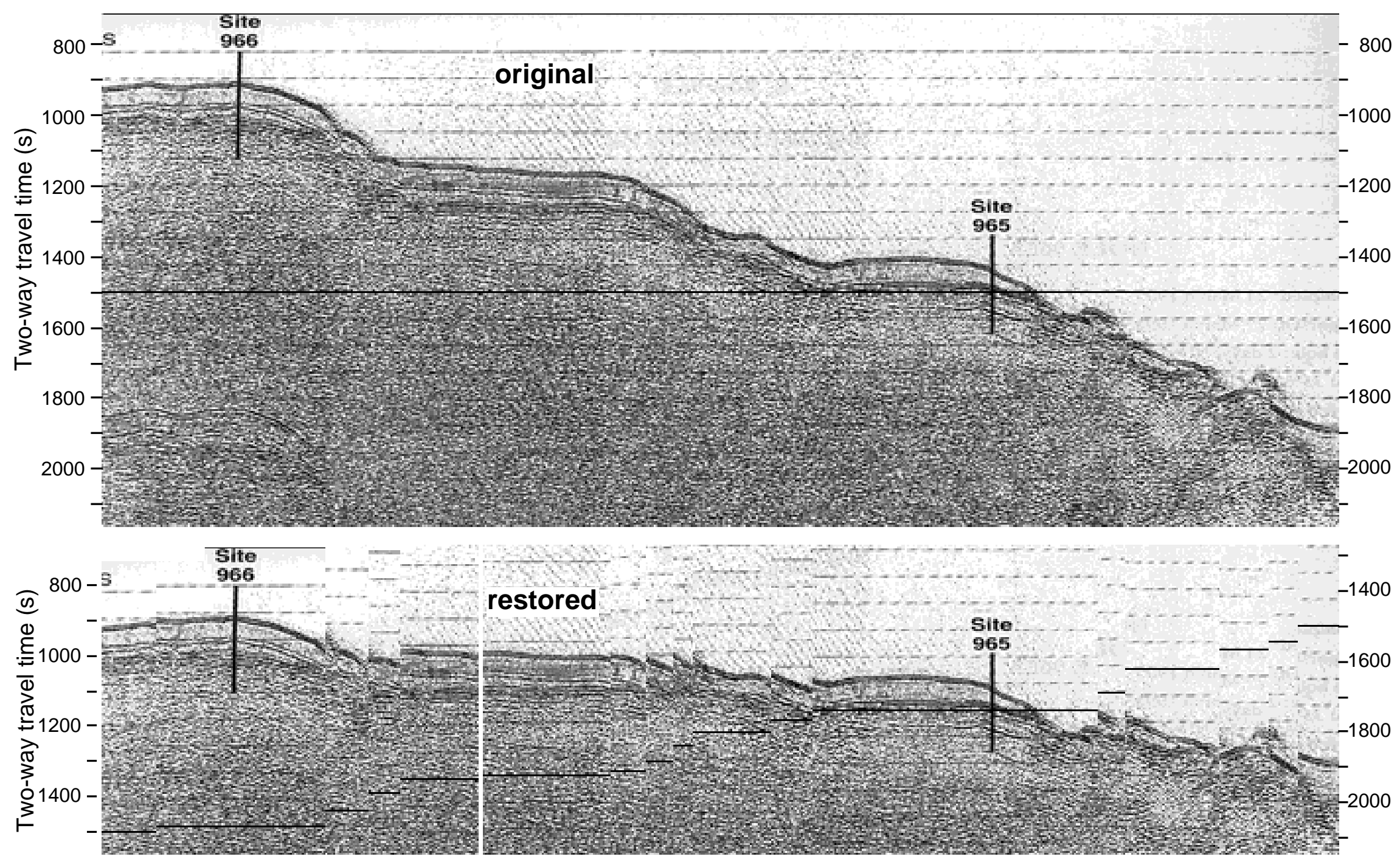

$4 \mathrm{~km}$

Figure 21. An extreme restoration of the sea bed between Sites 966 and 965 on the Eratosthenes Seamount obtained by considering that each step in the seismic reflection profile represents a steeply dipping fault. The relief is then nulled to align the prominent sub-bottom reflector corresponding to the top of the Miocene platform carbonates. This approach reduces the depth difference between the two sites by $350 \mathrm{~m}$, but assumes that the observed relief is predominantly tectonic and not aggradational in origin. It also assumed that any fault-generated relief is post-Miocene in age. 
Table 8. Observations and derived results to restore the edifice of Eratosthenes Seamount.

\begin{tabular}{lrrr}
\hline \multicolumn{1}{c}{ Configuration } & Hole & Hole & Hole \\
& $966 \mathrm{~F}$ & $965 \mathrm{~A}$ & $967 \mathrm{E}$ \\
\hline Present depth of seabed (mbsl) & 923 & 1507 & 2564 \\
Lateral distance from site 966 (km) & 0 & 14 & 25 \\
Depth to base of Pliocene (mbs) & 992 & 1536 & 2668 \\
Delta depth relative to 966F at present time (m) & 0 & 584 & 1641 \\
Delta depth relative to 966 for base of Pliocene (m) & 0 & 544 & 1676 \\
Restored delta depth relative to 966 for base of & 0 & 194 & 976 \\
$\quad$ Pliocene by unfaulting the seabed (m) & & & \\
Restored delta depth relative to 966 for base of & 0 & 0 & 627 \\
$\quad$ Pliocene by additional untilting the plateau by & & & \\
$0.8^{\circ}(\mathrm{m})$ & & & \\
\end{tabular}

Notes: These observations and derived results are from a simple exercise to restore the edifice of Eratosthenes Seamount by unfaulting the plateau to align the regional $\mathrm{M}$ reflector across every observed scarp in reflection profiles that link the sites and by untilting the fault-restored edifice to bring Site 965 at the rim of the summit back to the same elevation as Site 965 near its crest. This exercise shows that Site 967 at the base of the northern flank had to have been at least $627 \mathrm{~m}$ deeper than the summit prior to tectonic modification of the relief. Thus, even under conditions of extreme faulting and tilting, only $45 \%$ of the observed subsidence of Site 967 between the Late Miocene and the present can be so derived. The greater fraction of the subsidence must result from other causes such as loading by the surrounding thick cover of Messinian evaporites and the Pliocene-Quaternary sedimentary wedge of the Nile Fan

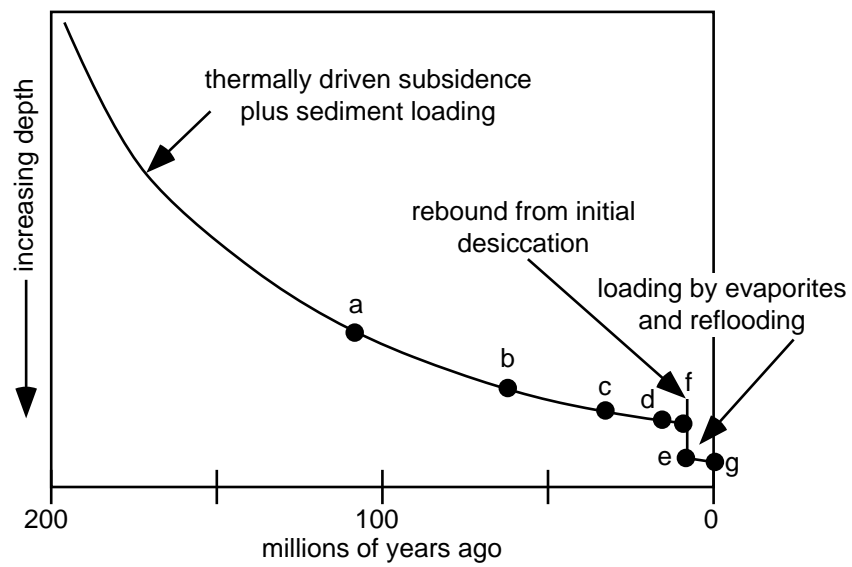

Figure 23. Schematic picture of the thermally driven subsidence that produced the evolution illustrated in Figure 24. The letters A-G indicate the intervals portrayed in the various panels of Figure 24. The step between 6 and 5 million years represents the initial isostatic unloading of the floor of the eastern Mediterranean upon the first episode of evaporitic drawdown, followed by a major loading from a 1.5 to $2.0 \mathrm{~km}$ thick layer of salt, anhydrite, dolomite and interbedded clastics. Most of the thermally driven component of subsidence is accomplished within the first 60 to 80 million years of the basin's formation.

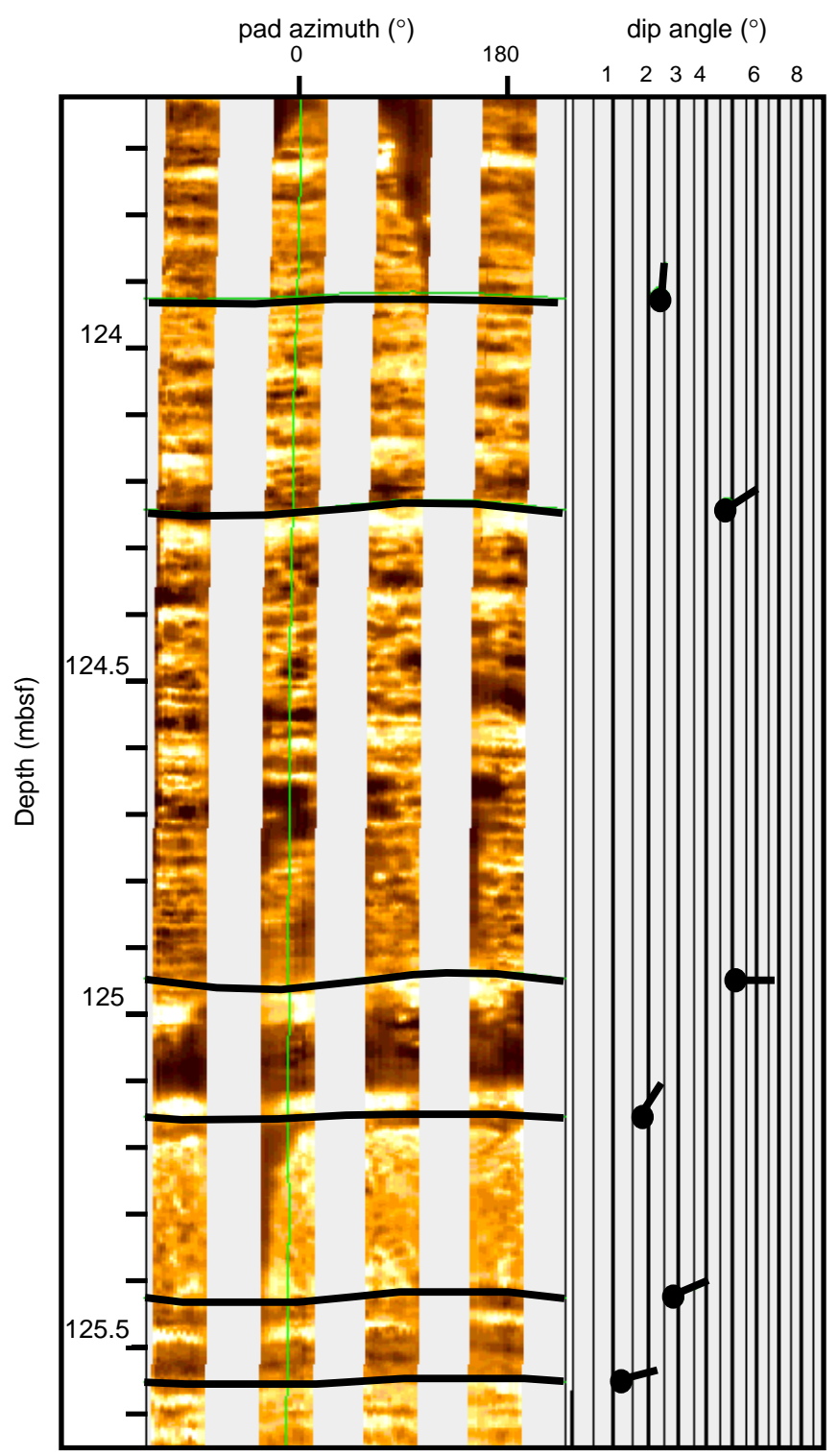

Figure 22. Dips calculated from Formation MicroScanner (FMS) image. The four FMS pads cover the borehole wall in 4 orthogonal directions. Sinusoids depict the intersection of a dipping plane with the borehole wall (Serra, 1989). 

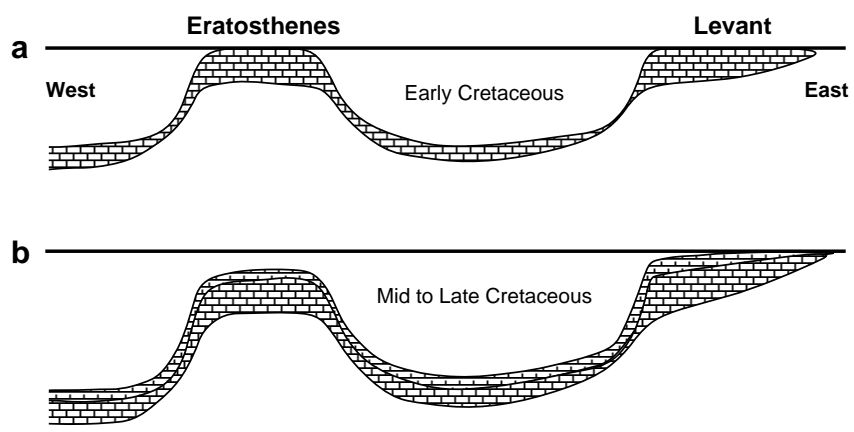

C
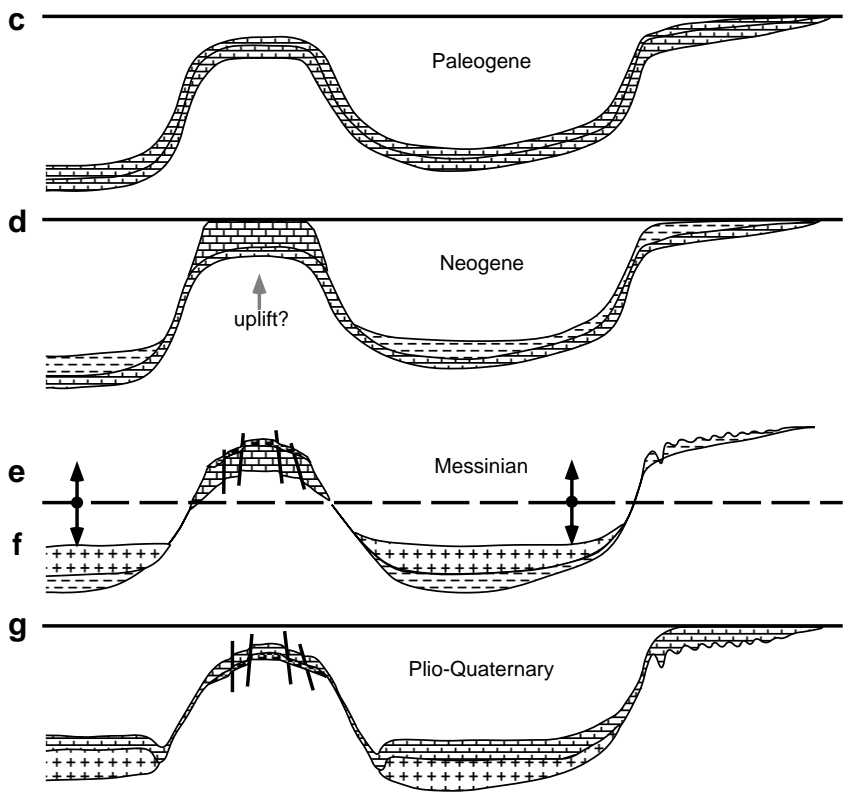

Figure 24. Schematic evolutionary history of Eratosthenes Seamount shown in the context of the nearby Levant continental margin. This history is based on a simple scheme of thermally driven subsidence and sedimentary aggradation consistent with the sedimentary record recovered by drilling and inferred from the borehole logs. For continuity, the panels, except for the topmost one, show the sediment unit which accumulated during the noted interval of time as well as that which formed during the previous one. A. Early Cretaceous interval of rapid and thick aggradation of shallow-water limestones in an atoll-like setting with accommodation spaced generated by the subsidence of the lithosphere from its thermal contraction. B. Mid- to Late Cretaceous interval of much slower biogenic pelagic sedimentation accompanying rising sea level after the plateau had drowned. Here the excess accommodation space is supplied by both continued and slower subsidence and by global eustacy. C. Paleogene interval of starved biogenic sedimentation in a pelagic setting. D. Neogene interval represented by a shallowing-upward sequence of carbonate sediments leading to reef building in the photic zone on the crest of the edifice (Porites). Sediments in the peripheral basins are dominantly terrigenous and reflect the Miocene initiation of the Nile delta and its offshore deep-sea fan. The shallowing environment on the seamount cannot be entirely accomplished by the observed thickness of the Miocene limestones, and thus some other process (such as the overall elevation of the African continent) must have played some role. E, F. The brief drawdown interval of the Messinian stage of the terminal Miocene during which thick evaporites formed in the deeper basins during episodes of complete or partial desiccation. During this phase the summit of the Eratosthenes Seamount was often exposed to subaerial weathering processes, leading to diagenesis from the action of meteoric waters. The matrix-supported breccia on the summit is the product of erosion and dissolution resulting in extensive karst, soils, and lacustrine deposits. Such denudation produced a highamplitude dendritic drainage in siliciclastic strata on the exposed African and Levant margins. The eroded materials were delivered to the basin floor to become interbedded with the evaporites. G. Pliocene and Quaternary interval of relatively slow biogenic pelagic sedimentation in a bathyal environment on the drowned summit and flank of the plateau. 
Plate 1. Photomicrographs of thin sections from Hole 966F on the summit of Eratosthenes Seamount. 1. Sample 160-966F-7R-1, 12 cm, wackestone/packstone $6.3 \times$ objective $(63 \times$ total magnification) plane polarized light. This photo shows several ostracodes and one large mollusc mold partly filled with blocky carbonate cement. Matrix is partially recrystallized micrite. 2. Sample $160-966 \mathrm{~F}-9 \mathrm{R}-1,5 \mathrm{~cm}$, bioclastic grainstone/packstone $2.5 \times$ objective $(25 \times$ magnification $)$ polarized light. This photo shows gastropods, foraminifers, and unidentified micritized (bio)clasts in a matrix of finely crystalline sparite. Shell interiors and solution cavities are filled with coarsely crystalline spar. 3. Sample 160-966F-10R-1, $44 \mathrm{~cm}$, algae; $6.3 \times$ objective, polarized light. This photo shows a solution cavity within a large clump of algae partially filled with coarsely crystalline spar. 4. Sample 160-966F-12R-1, $13 \mathrm{~cm}$, coral; $6.3 \times$ objective, polarized light. This photo shows a coral fragment that has undergone dissolution and partial infilling of resulting void space by blocky spar. 5. Sample 160-966F-19R-2, 35 cm, dolomitized algal packstone; $6.3 \times$ objective, plane polarized light. This photo shows a large algal filament in the lower left hand corner. Matrix is pervasively recrystallized, partly obliterating smaller clasts. Small dolomite rhombs are visible within the matrix. 6. Sample 160-966F-25R-1, $6 \mathrm{~cm}$, packstone. This photo shows abundant planktonic foraminifers, with less common echinoderm fragments. A cemented fracture runs diagonally across the photo. 7. Sample 160-966F-26R-1, $9 \mathrm{~cm}$, bioclastic packstone/grainstone. $2.5 \times$ objective, plane polarized light. This photo an abundance of bioclastic debris, with a large echinoderm with syntaxial cement. Planktonic foraminifers are common. The large micrite clast on the right side of the photo is an interclast. 

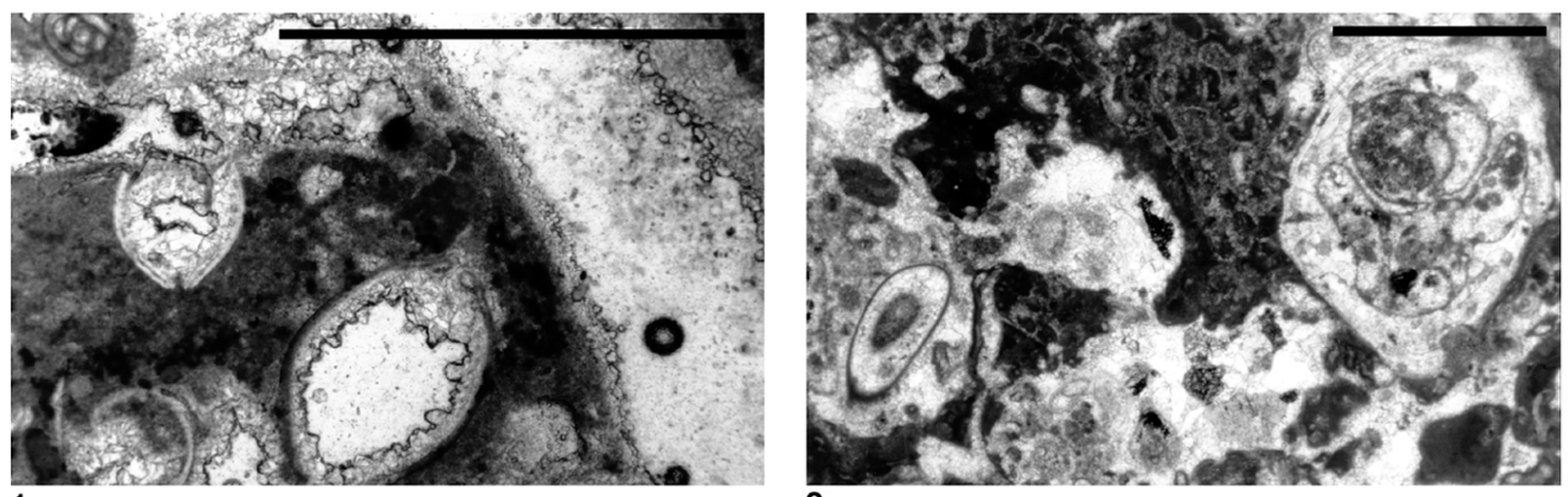

1

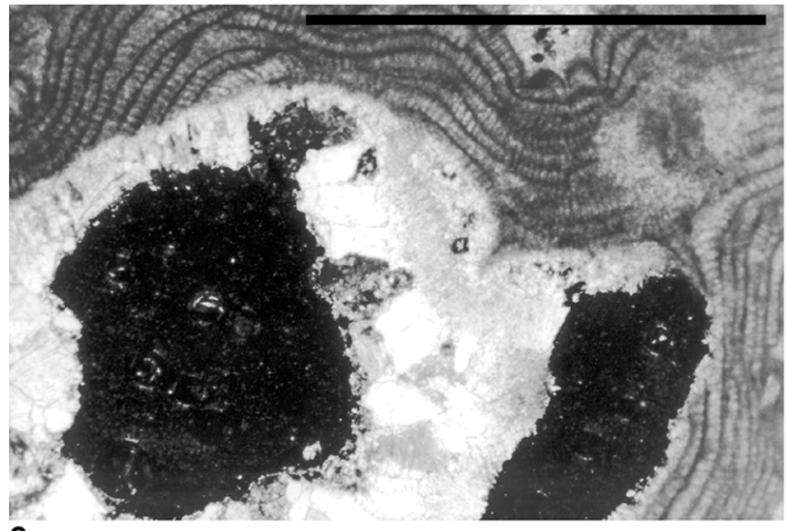

3

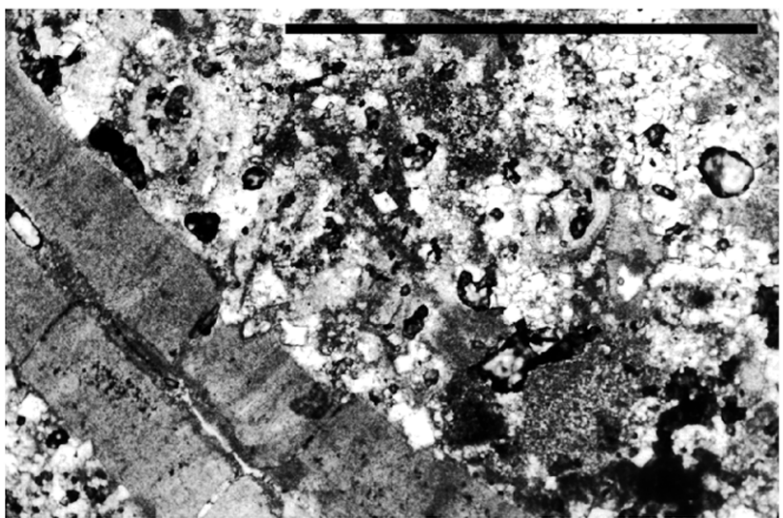

5

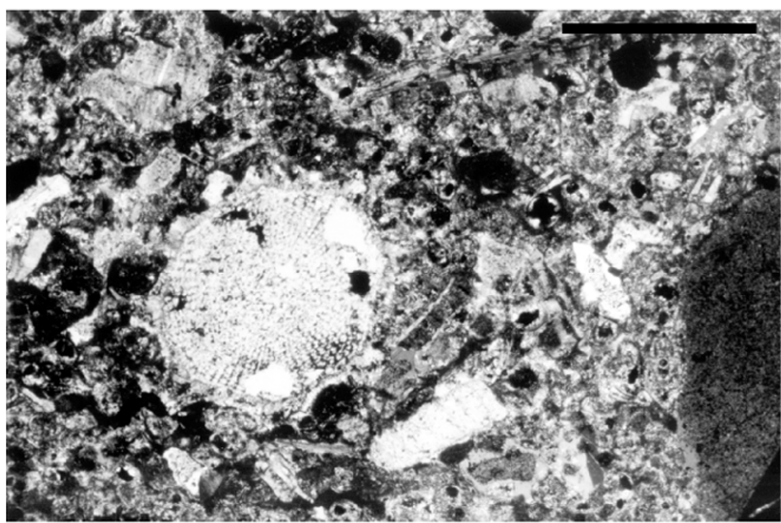

\section{2}
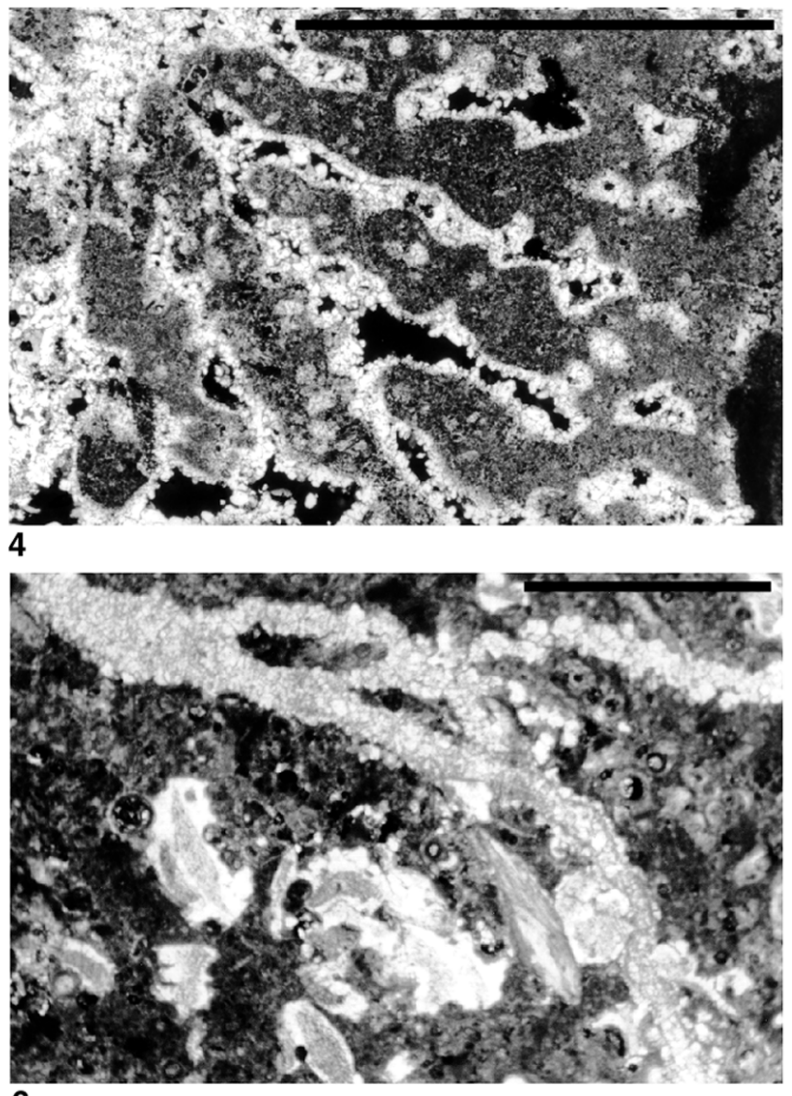

6 


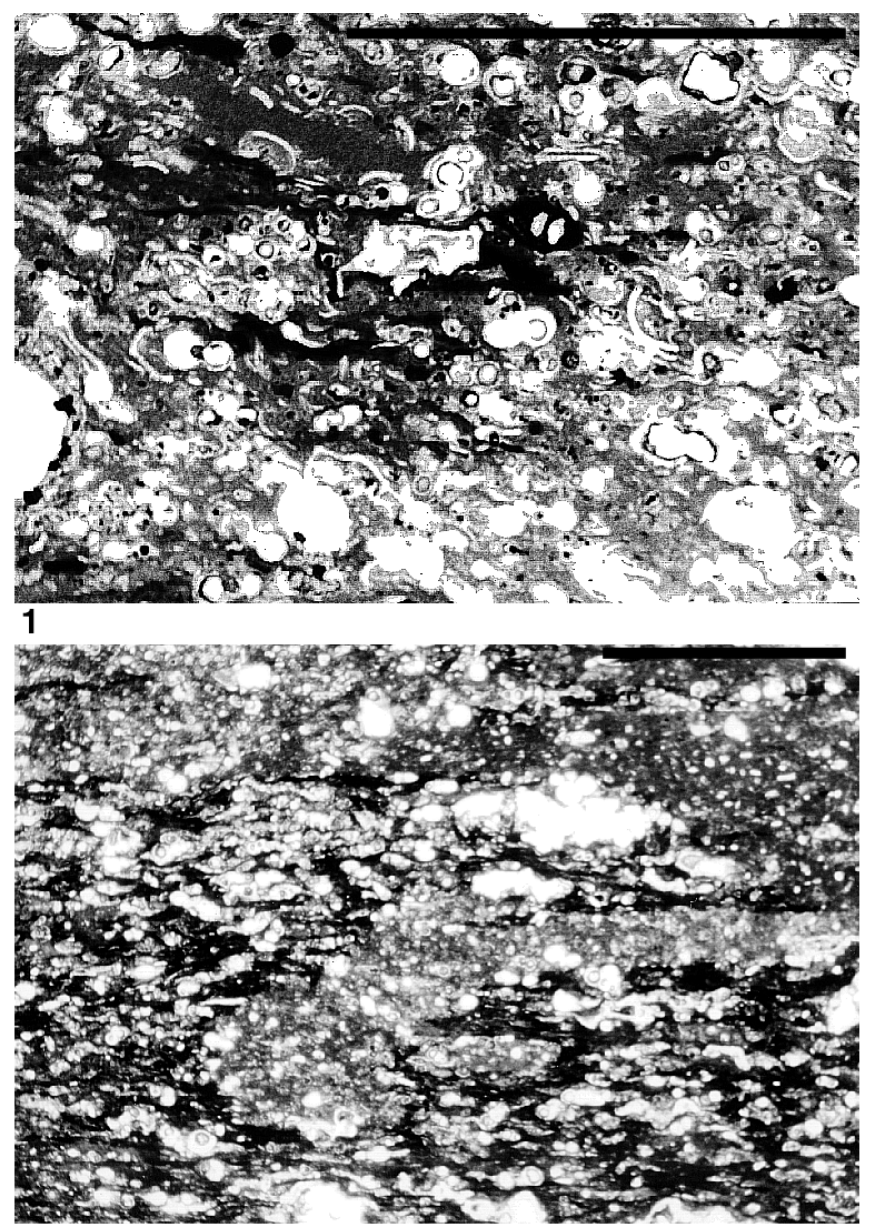

2

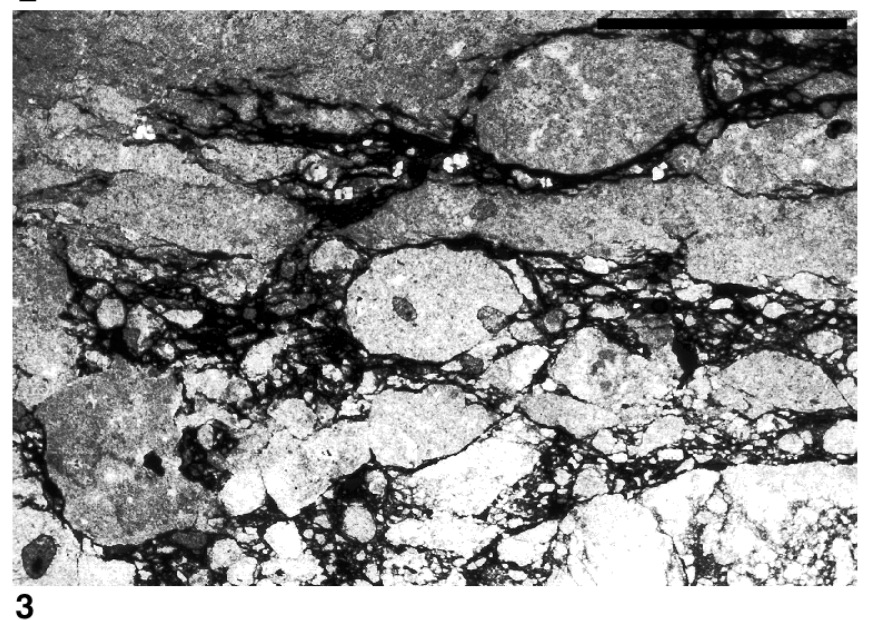

Plate 2. Photomicrographs of thin sections from Hole 967E at the base of the northern flank of Eratosthenes Seamount. 1. Sample 160-967E-13R-1, 97 cm, foraminiferal wackestone/packstone; $6.3 \times$ objective, plane polarized light. This photo shows abundant planktonic foraminifers suspended in a micrite matrix. Black spots are opaque minerals, probably pyrite. 2. Sample 160-967E-28R-1, $117 \mathrm{~cm}$, foraminiferal wackestone, $2.5 \times$ objective, plane polarized light. This photo shows a foram wackestone in a dark, organic-rich matrix. The lighter, irregularly shaped features in the middle of the image is a burrow. Note the horizontal fabric (probably caused by compaction). 3. Sample $1610-967 \mathrm{E}-49 \mathrm{R}-1,8 \mathrm{~cm}$, grainstone/carbonate breccia $2.5 \times$ objective plane polarized light. This photo shows angular clasts with dark micrite in the interstices. This texture is thought to be the result of cataclastic deformation. 